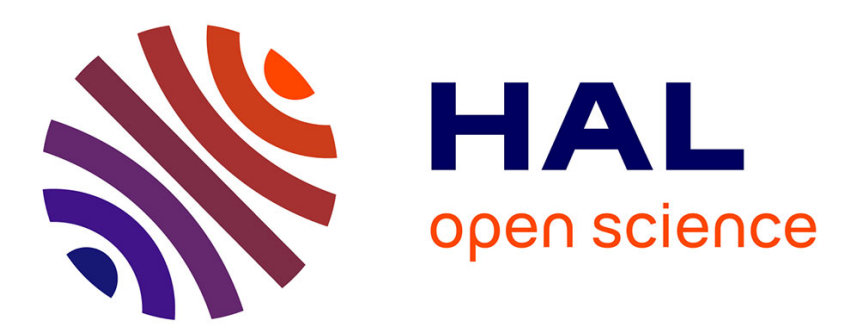

\title{
Critical evaluation of climate syntheses to benchmark CMIP6/PMIP4 127 ka Last Interglacial simulations in the high-latitude regions
}

\author{
E. Capron, A. Govin, R. Feng, B.L. Otto-Bliesner, E.W. Wolff
}

\section{- To cite this version:}

E. Capron, A. Govin, R. Feng, B.L. Otto-Bliesner, E.W. Wolff. Critical evaluation of climate syntheses to benchmark CMIP6/PMIP4 127 ka Last Interglacial simulations in the high-latitude regions. Quaternary Science Reviews, 2017, 168, pp.137 - 150. 10.1016/j.quascirev.2017.04.019 . hal-01584123

\section{HAL Id: hal-01584123 \\ https://hal.science/hal-01584123}

Submitted on 24 Jun 2021

HAL is a multi-disciplinary open access archive for the deposit and dissemination of scientific research documents, whether they are published or not. The documents may come from teaching and research institutions in France or abroad, or from public or private research centers.
L'archive ouverte pluridisciplinaire HAL, est destinée au dépôt et à la diffusion de documents scientifiques de niveau recherche, publiés ou non, émanant des établissements d'enseignement et de recherche français ou étrangers, des laboratoires publics ou privés. 
1 Critical evaluation of climate syntheses to benchmark CMIP6/PMIP4 127 ka Last Interglacial

2 simulations in the high-latitude regions.

3 E. Capron ${ }^{1,2}$, A. Govin ${ }^{3}$, R. Feng ${ }^{4}$, B. L. Otto-Bliesner ${ }^{4}$ and E. W. Wolff ${ }^{5}$

$4{ }^{1}$ Centre for Ice and Climate, Niels Bohr Institute, University of Copenhagen, Juliane Maries Vej 30, DK-2900,

5 Copenhagen, Denmark;

$6 \quad{ }^{2}$ British Antarctic Survey, High Cross, Madingley Road, Cambridge CB3 0ET, UK;

$7 \quad{ }^{3}$ LSCE/IPSL, Laboratoire des Sciences du Climat et de l'Environnement (CEA-CNRS-UVSQ), Université Paris-

8 Saclay, 91190 Gif-Sur-Yvette, France;

$9{ }^{4}$ Climate and Global Dynamics Laboratory, National Center for Atmospheric Research (NCAR), Boulder, CO

10 80305, USA;

$11 \quad 5$ Department of Earth Sciences, University of Cambridge, CB2 3EQ Cambridge, UK.

12 Corresponding author: capron@nbi.ku.dk

13 Abstract:

The Last Interglacial (LIG, 129-116 thousand years ago, ka) represents an excellent case study to investigate the response of sensitive components of the Earth System and mechanisms of high-latitude amplification to a climate warmer than present-day. The Paleoclimate Model Intercomparison Project (Phase 4, hereafter referred as PMIP4) and the Coupled Model Intercomparison Project (Phase 6, hereafter referred as CMIP6) are coordinating the design of (1) a LIG Tier 1 equilibrium simulation to simulate the time slice at $127 \mathrm{ka}$, a time interval associated with a strong orbital forcing and greenhouse gas concentrations close to preindustrial levels and (2) associated Tier 2 sensitivity experiments to examine the role of the ocean, vegetation and dust feedbacks in modulating the response to this orbital forcing.

Evaluating the capability of the CMIP6/PMIP4 models to reproduce the 127 ka polar and sub-polar climate will require appropriate data-based benchmarks which are currently missing. Based on a recent data synthesis that offers the first spatio-temporal representation of high-latitude (i.e. poleward of $40^{\circ} \mathrm{N}$ and $40^{\circ} \mathrm{S}$ ) surface temperature evolution during the LIG, we produce a new 126-128 ka time slab, hereafter named 127 ka time slice. This 127 ka time slice represents surface temperature anomalies relative to preindustrial and associated with quantitative estimates of the uncertainties related to relative dating and surface temperature reconstruction methods. It illustrates warmer-than-preindustrial conditions in the high-latitude regions of both hemispheres. In particular, summer sea surface temperatures (SST) in the North Atlantic region were on average $1.1^{\circ} \mathrm{C}$ (with a standard error of the mean of $0.7^{\circ} \mathrm{C}$ ) warmer relative to preindustrial and $1.8^{\circ} \mathrm{C}$ (with a standard error of the mean of $0.8^{\circ} \mathrm{C}$ ) in the Southern Ocean. In Antarctica, average 127 ka annual surface air temperature was $2.2^{\circ} \mathrm{C}$ (with a standard error of the mean of $1.4^{\circ} \mathrm{C}$ ) warmer compared to preindustrial.

We provide a critical evaluation of the latest LIG surface climate compilations that are available for evaluating LIG climate model experiments. We discuss in particular our new 127 ka time-slice in the context of existing LIG surface temperature time-slices. We also compare the $127 \mathrm{ka}$ time slice with the ones published for the125 and 130 ka time intervals and we discuss the potential and limits of a data-based time slice at $127 \mathrm{ka}$ in the context of the upcoming coordinated modeling exercise. Finally we provide guidance on 
the use of the available LIG climate compilations for future model-data comparison exercises in the framework of the upcoming CMIP5/PMIP4 127 ka experiments. We do not recommend the use of LIG peak warmth-centered syntheses. Instead we promote the use of the most recent syntheses that are based on coherent chronologies between paleoclimatic records and provide spatio-temporal reconstruction of the LIG climate. In particular, we recommend using our new 127 ka data-based time slice in model-data comparison studies with a focus on the high-latitude climate.

Key words: Last Interglacial, 127 ka surface temperature time slice, CMIP6/PMIP4 Tier 1 and Tier 2 simulations, quantitative uncertainty estimates attached to relative dating and temperature reconstruction methods.

\section{Introduction:}

Understanding the climate processes and feedbacks occurring in high-latitude regions is essential for predicting future high-latitude responses to rising atmospheric $\mathrm{CO}_{2}$ concentrations. These areas are amongst the most affected by global climate change due to their sensitivity to changes in radiative forcing, and they act as amplifiers of climate change through changes in snow and ice cover and associated albedo feedbacks (e.g. Hartmann et al., 2013; Vaughan et al., 2013). The high latitudes provide also the climatic context responsible for polar ice sheet melting and consequently, sea level changes (e.g. DeConto and Pollard, 2016). Besides, surface oceanic conditions (e.g. temperature, salinity) in the Nordic Seas and North Atlantic Ocean play a key role in modulating the intensity of the Atlantic Meridional Overturning Circulation (AMOC), responsible for meridional heat transport and heat and carbon storage in the ocean (e.g. Wunch, 2002). However uncertainties remain in the ability of climate models (1) to correctly capture feedbacks involved in polar amplifications (e.g. Braconnot et al. 2012; Schmidt et al., 2014) and (2) to assess future climate changes in the North Atlantic that will affect the stability of the AMOC (e.g. Sgubin et al., 2017).

The Last Interglacial (LIG, 129-116 thousand years BP, ka; Figure 1) represents an appropriate case study to test the skills of climate models and to assess feedbacks accounting for the amplified high-latitude warmth in a range of temperature changes comparable to present-day and projected changes in the near future. A recent study suggests that LIG peak global mean annual sea surface temperatures (SST) were $0.5 \pm$ $0.3^{\circ} \mathrm{C}$ warmer than the preindustrial climatological mean (calculated from 1870 to 1889 ) but indistinguishable from the 1995 to 2014 climatological mean (Hoffman et al., 2017). Considering that LIG global sea level was up to 6 to $9 \mathrm{~m}$ higher-than-today (e.g. Dutton et al., 2015), this warming trend raises

68 further concerns on the response of the high-latitude regions to a globally warmer-than-preindustrial climate 69 and the vulnerability of Greenland and Antarctica to climate change. Processes and feedbacks at play during 70 the LIG are not yet fully understood and in particular large-scale discrepancies currently exist between LIG 71 simulations and reconstructions for the surface temperature trends over the polar and sub polar regions (e.g. 72 Lunt et al., 2013; Bakker et al., 2013; Otto-Bliesner et al., 2013). 
The Coupled Model Intercomparison Project (CMIP) and Paleoclimate Model Intercomparison Project

(PMIP) coordinate climate and paleoclimate modelling activities and evaluate the capability of models used in future climate projections to reproduce past climates (WCRP-Coupled-Model-Intercomparison-ProjectPhase-5, 2011, Braconnot et al., 2012). In the framework of both Phase 6 of CMIP (CMIP6) and Phase 4 of PMIP (PMIP4), an experimental protocol for LIG Tier 1 equilibrium simulations referred to as lig127k has been prepared recently (Kageyama et al., 2017; Otto-Bliesner et al. 2016). 127 ka was identified as the most appropriate time interval to investigate the impact of a stronger orbital forcing compared to the preindustrial at a time when atmospheric greenhouse gas concentrations were similar to preindustrial levels and the continental configurations were almost identical to modern (Figure 1). It also occurs sufficiently late within the LIG to only bear a limited climate imprint of the melting of the Northern Hemisphere ice sheets during the penultimate deglaciation (Govin et al., 2012; Otto-Bliesner et al., 2016).

One of the objectives of this lig127k equilibrium simulation is to examine the connections among large scale and regional climate changes leading to changes in land-sea contrast and amplified warming in the high latitudes under a strong orbital forcing context (Otto-Bliesner et al., 2016). To facilitate diagnosis of the Tier 1 lig127k equilibrium experiment, Tier 2 sensitivity simulations are also proposed to examine the impact of uncertainties attached to the boundary conditions and the role of the cryosphere, ocean, vegetation and dust feedbacks in modulating the response to this orbital forcing. In particular, one of the sensitivity experiments will explore the climate response to the release of freshwater into the North Atlantic Ocean (due to Northern Hemisphere ice sheet melting) and the role of such freshwater forcing in generating millennialscale climate changes i.e. changes at a faster scale than what would be expected solely from the insolation forcing (Goelzer et al., 2016; Stone et al., 2016). Full information on the scientific objectives and design of the lig127k and associated sensitivity experiments can be found in Otto-Bliesner et al. (2016).

Evaluating these model simulations will require the use of appropriate paleoclimatic data syntheses as benchmarks. The syntheses of LIG quantitative climate reconstructions from Turney and Jones (2010) and McKay et al. (2011) have been used previously for climate model evaluation (Lunt et al., 2013; Otto-Bliesner et al., 2013). However, these compilations are attached to several limitations. First, they are based on paleoclimatic records taken on their original timescales, which introduce dating uncertainties of up to 6 ka (Govin et al., 2015). Second, they consist of a compilation of peak warmth values not occurring necessarily at the same time. Indeed, there is much evidence that the LIG warming was not synchronous globally (e.g. Bauch and Erlenkeuser, 2008; Cortese et al., 2007; NEEM-community-members, 2013; Govin et al., 2012; MassonDelmotte et al., 2010). Thus, the Turney and Jones (2010) and McKay et al. (2011) syntheses do not represent a climate state prevailing at any specific time periods across the LIG, but instead a virtual image on the LIG peak warmth across the globe. As a result and despite their global geographical extent, the Turney and Jones (2010) and McKay et al. (2011) datasets represent inadequate benchmarks for the upcoming lig127k simulation and associated sensitivity experiments.

We overcame the difficulty of harmonizing chronologies of marine and ice records from different hemispheres using a strategy based on climato-stratigraphic alignments (Capron et al., 2014). We produced a 
spatio-temporal representation of the LIG climate in the high-latitude regions using annual surface air

111 temperature and summer SST from polar ice and marine records above latitudes of $40^{\circ} \mathrm{N}$ and $40^{\circ} \mathrm{S}$. We also

112 proposed four maps of surface temperature anomalies relative to present-day calculated for 2 ka- time slices centred on 130, 125, 120 and $115 \mathrm{ka}$. This time-evolving synthesis and associated time-slices provide robust data anchors to evaluate climate model capability in representing LIG processes and feedback mechanisms occurring in polar and sub-polar regions (Capron et al., 2014; Loutre et al., 2014; Stone et al., 2016; Pfeiffer and Lohmann, 2016). Following a similar climato-stratigraphic approach, Hoffman et al. (2017) built recently a compilation of annual sea surface temperature records extending down to the tropics, together with three associated maps of SST anomalies at 129, 125 and $120 \mathrm{ka}$.

Despite those recent progresses, no time slice centred on the $127 \mathrm{ka}$ time interval chosen to run the CMIP5/PMIP4 LIG Tier 1 and Tier 2 experiments is available. Yet, studies have illustrated how crucial it is to compare climate simulations with the appropriate paleo-data time period. For instance, snapshot experiments performed by Otto-Bliesner et al. (2013) with the General Coupled Model (GCM) CCSM3 for the $130 \mathrm{ka}, 125 \mathrm{ka}$ and $120 \mathrm{ka}$ time intervals, simulate North Atlantic sea surface temperatures (SST) that range from little change relative to preindustrial values for 120 ka to 2 to $6^{\circ} \mathrm{C}$ maximum warming for 125 and 130 ka. These diverse warming signals simulated at different time intervals could not be evaluated by the LIG peak warmth-centred syntheses such as those from Turney and Jones (2010) and McKay et al. (2011), calling for syntheses at the corresponding time periods. Moreover, a study highlighted that when forced by the 130 ka orbital configuration and GHG levels only, the CCSM3 and HadCM3 models could not reproduce the interhemispheric asynchrony observed in the surface temperature response at $130 \mathrm{ka}$ (Capron et al., 2014). This observation cannot be drawn without comparing the simulations to the data time slice corresponding to 130 ka. Building upon this observation, the model-data mismatch was then resolved when accounting for an additional forcing associated with a freshwater input in the North Atlantic to account for Northern Hemisphere ice sheet melting across the penultimate deglaciation (Stone et al., 2016).

In this study, we present a new 126-128 ka (hereafter referred to as $127 \mathrm{ka}$ ) time slice of surface temperature anomalies relative to preindustrial based on the Capron et al. (2014) synthesis to assist the assessment of the CMIP5/PMIP4 LIG Tier 1 and Tier 2 simulations in the high-latitude regions. After a brief description of the materials and methods (Section 2), we describe the main climatic features highlighted in the 127 ka time slice and differences with the ones existing for 130 and 125 ka (section 3). Finally, we compare our new 127 ka time slice with other existing LIG data syntheses, evaluating their strengths and limitations. We also discuss the validity of such a data time slice at $127 \mathrm{ka}$ in the context of the upcoming modeling exercise (Section 4).

\section{Material and Methods}


ka for latitudes above $40^{\circ} \mathrm{N}$ and $40^{\circ} \mathrm{S}$. Surface air temperature records are deduced from ice core water isotopic profiles. Sea surface temperatures (SST) are reconstructed in marine cores from foraminiferal Mg/Ca ratios, alkenone unsaturation ratios or microfossil faunal assemblage transfer functions (Figure 1 and Table

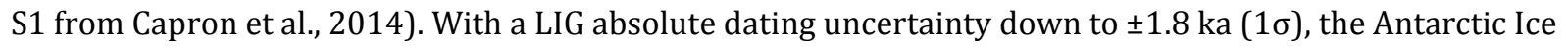
Core Chronology 2012 (hereafter referred to as AICC2012; Bazin et al., 2013; Veres et al., 2013) is chosen as the reference age scale for all paleoclimatic records. Marine records are transferred onto AICC2012 by assuming that surface-water temperature changes in the sub-Antarctic zone of the Southern Ocean (respectively in the North Atlantic) occurred simultaneously with air temperature variations above Antarctica (respectively Greenland). Details on the climate record alignments are presented in Capron et al. (2014).

We calculate temperature averages for the 126-128 ka interval to account for the record temporal resolution, dating uncertainties and potential delays in climate responses. Instead of using temperature anomalies relative to modern-day as in Capron et al. (2014), we calculate temperature anomalies relative to preindustrial to facilitate comparisons with the LIG Tier 1 simulation for which boundary conditions and forcing will be set relative to preindustrial. For each marine core location, we extracted the preindustrial SST from the HadISST dataset for the 1870-1899 interval (Rayner et al., 2003). For our marine core locations, the gridded NODC WOA98 summer SST dataset (representative of modern-day) is on average $0.1^{\circ} \mathrm{C}$ warmer than the gridded 1870-1899 HadISST dataset in the North Atlantic region and $0.2^{\circ} \mathrm{C}$ cooler in the Southern Ocean (see Table S1). Note that HadISST is a statistically blended and interpolated dataset of different measurements, representing optimal SST spatial distributions. Uncertainties associated to the HadISST are not currently available (Rayner et al., 2003). These HadISST values at the marine core sites cannot be tested against in-situ preindustrial SST reconstructions since the paleorecords selected for the LIG synthesis do not have a sufficient resolution to correctly establish the pre-industrial climate. Yet, the HadISST is shown to be consistent with other datasets across overlapping time span, therefore its uncertainties are likely small (Rayner et al., 2003), especially in comparison to the typical error related to the SST reconstructions included in our study. The preindustrial estimate $\left(-28.8 \pm 0.7^{\circ} \mathrm{C}\right)$ of the Greenland NEEM ice core site is based on borehole temperature measurements (Masson-Delmotte et al., 2015). In the absence of such reconstructions for the Antarctic sites, the estimates corresponding to the 1870-1899 time interval rely on water isotopic profiles, they are similar to modern instrumental ones within less than $1^{\circ} \mathrm{C}$ except for EDML (less than $2^{\circ} \mathrm{C}$; $\mathrm{A}$. Orsi, personal communication).

We calculate 127 ka surface temperature anomalies relative to preindustrial and temperature differences between (1) 127 and $130 \mathrm{ka}$ and (2) 125 and $127 \mathrm{ka}$, all associated with quantitative uncertainties by following the methodology presented in Capron et al. (2014). Briefly, we apply to both ice core and marine records a Monte Carlo analysis performed with 1000 age model simulations. For each site, it relies on the surface temperature record resampled every 0.1 ka after being transferred onto AICC2012 by linear interpolation between the defined tie points (details in Table S2 from Capron et al., 2014). From 1000 slightly different SST anomalies obtained for the 126-128 ka time windows, we calculated the median 127 ka surface 
temperature anomaly and associated confidence intervals $(2 \sigma)$ defined by the $2.5^{\text {th }}$ and $97.5^{\text {th }}$ percentiles. These non-parametric uncertainties take into account temperature reconstruction errors and relative dating uncertainties. The $127 \mathrm{ka}$ average uncertainty is $\sim 3.0^{\circ} \mathrm{C}(2 \sigma)$. Similar procedure is followed to deduce the temperature differences between (1) 127 and $130 \mathrm{ka}$ and (2) 125 and $127 \mathrm{ka}$, and their respective $2 \sigma$ uncertainties.

Note that originally this approach was not used for ice core records in Capron et al. (2014) and only the uncertainty associated with temperature reconstructions based on water isotopic profiles, i.e. $1.5^{\circ} \mathrm{C}$ and $4^{\circ} \mathrm{C}$ for Antarctic and Greenland ice core records respectively was provided. Now, time slice surface air temperature and associated $2 \sigma$ errors are estimated also for ice core-based temperature records following the same Monte-Carlo based-procedure as for SST reconstructions. While EDC, EDML, Vostok and Talos Dome records are not associated with relative dating errors since they were directly used to produce the reference AICC2012 chronology (Bazin et al., 2012; Veres et al., 2012), we consider relative dating uncertainties associated with the transfer of the NEEM and Dome F records onto AICC2012, in addition to temperature reconstruction errors. For the Dome F ice core, we use an updated site temperature reconstruction (Uemura et al., 2012), it leads to differences of only $0.6^{\circ} \mathrm{C}$ and $0.1^{\circ} \mathrm{C}$ for the 130 and 125 ka temperature estimates respectively. Published and updated 130,127, 125, 120 and 115 ka surface temperature estimates and associated $2 \sigma$ errors are provided in Table S1.

We also provide regional mean SST anomalies for the North Atlantic, the Southern Ocean and Antarctica at 130, 127 and 125 (Table 1). Because of the little amount of records available but also the larger dating uncertainties, we prefer to avoid providing average SST anomalies for the Labrador and Norwegian Seas. Also an average value cannot be provided for Greenland since only one quantitative temperature reconstruction (for the NEEM site) is available so far. The North Atlantic and the Southern Ocean average estimates were calculated by averaging anomalies in $8^{\circ} \times 8^{\circ}$ boxes after weighting each zonal average by the area of ocean for each latitudinal band. The Antarctic averages were calculated using the same method and grid box resolution. Note that we also apply the same methodology to the 129, 127 and 125 ka SST anomalies from North Atlantic and Southern Ocean sites above $40^{\circ} \mathrm{N}$ and $40^{\circ} \mathrm{S}$ respectively presented in the recent Hoffman et al. (2017). Details are given in the Supplementary Material.

\section{Results}

The 127 ka time slice illustrates mostly warmer than preindustrial conditions in both hemispheres (Figure 2). The area-weighted average summer SST warming relative to preindustrial was $1.1^{\circ} \mathrm{C}$ (with a $0.7^{\circ} \mathrm{C}$ standard error of the mean, noted SE hereafter) in the North Atlantic and $1.8^{\circ} \mathrm{C}\left(\mathrm{SE}: 0.8^{\circ} \mathrm{C}\right)$ in the Southern Ocean (using 14 and 15 reconstructions respectively, Table 1). However, colder than preindustrial conditions are mostly recorded in the Nordic Seas. A Nordic Seas average SST estimate is not proposed here because of the paucity of available records, reduced proxy sensitivity to record low SST variations and large chronological uncertainties (Capron et al., 2014). In Antarctica, the area-weighted average $127 \mathrm{ka}$ annual surface air temperature was $2.2\left(\mathrm{SE}: 1.4^{\circ} \mathrm{C}\right)$ warmer compared to preindustrial (using four records). Only one 
quantitative surface air temperature reconstruction above Greenland covering unambiguously the LIG is currently available based on the NEEM ice core water isotopic record. It results in a precipitation-weighted temperature estimate warmer by $7.8 \pm 7.9^{\circ} \mathrm{C}(2 \sigma)$ at 127 ka (NEEM-community-members, 2013), however a value possibly twice as small was suggested through the recent work from Masson-Delmotte et al. (2015). The correct value remains under discussion (Landais et al., 2016).

Surface temperature anomaly calculations between 127 and 130 ka and between 125 and $127 \mathrm{ka}$ (Figure 2, Table 1) highlight differences and similarities between the three intervals. North Atlantic summer SST (S-SST) are $5.3 \pm 1.0^{\circ} \mathrm{C}$ (mean squared error) warmer at 127 ka compared to 130 ka while small differences are observed between 125 and 127 ka $\left(0.1 \pm 1.0^{\circ} \mathrm{C}\right)$. In the Southern Ocean, the 127 and $130 \mathrm{ka}$ time slices evidence a relatively similar pattern $\left(0.1 \pm 1.2^{\circ} \mathrm{C}\right.$ of temperature difference $)$ and a slight cooling is observed between 127 and $125 \mathrm{ka}\left(-0.3 \pm 1.2^{\circ} \mathrm{C}\right.$ difference). Larger differences are calculated for Antarctica with warmer conditions at 127 ka by $0.3 \pm 2.0^{\circ} \mathrm{C}$ and $0.9 \pm 2.0^{\circ} \mathrm{C}$ compared to 130 and 125 ka respectively.

\section{Discussion}

\subsection{On the potential remnant imprint of the millennial-scale bipolar seesaw pattern at $127 \mathrm{ka}$}

The hemispheric surface temperature patterns deduced at 127 ka from Capron et al. (2014) are very different compared to those observed at $130 \mathrm{ka}$ in the Capron et al. (2014) time slice (Figure 3). While the North Atlantic and the Southern Ocean are both warmer than preindustrial at $127 \mathrm{ka}\left(+1.1^{\circ} \mathrm{C}\right.$ with SE: $0.7^{\circ} \mathrm{C}$ and $+1.8^{\circ} \mathrm{C}$ with SE: $0.8^{\circ} \mathrm{C}$ respectively), at $130 \mathrm{ka}$, the North Atlantic temperatures are much cooler than preindustrial $\left(-4.2^{\circ} \mathrm{C}\right.$ with SE: $0.8^{\circ} \mathrm{C}$ on average) and the Southern Ocean was already warmer than preindustrial $\left(+1.8^{\circ} \mathrm{C}\right.$ with SE: $0.9^{\circ} \mathrm{C}$ on average). The differences for the North Atlantic region are clearly illustrated by the large warming calculated between 130 and $127 \mathrm{ka}\left(5.3 \pm 1.0^{\circ} \mathrm{C}\right)$ while only the small climatic difference observed between 125 and $127 \mathrm{ka}\left(0.1 \pm 1.0^{\circ} \mathrm{C}\right.$; Table 1$)$. These patterns are the expression of the asynchronous establishment of peak warmth observed between the Northern Hemisphere temperature records and those from the Southern Hemisphere (Figure 1). The LIG temperature peak in the Southern Hemisphere is reached at $129.3 \pm 0.9 \mathrm{ka}$ and at $126.4 \pm 1.9 \mathrm{ka}$ in the North Atlantic (Capron et al., 2014). This hemispheric asynchrony illustrated best in the 130 ka time slice from Capron et al. (2014) is attributed to dynamics independent from orbital forcing and related to the bipolar seesaw mechanism (Capron et al., 2014). This mechanism is likely related to the disruption of the Atlantic overturning circulation due to freshwater discharges into the North Atlantic (e.g. Govin et al.. 2012; Marino et al., 2015; Stone et al., 2016), leading to the northern high latitudes prolonged cold conditions while contributing to the southern high latitudes early warming (Broecker, 1998; Stocker and Johnsen, 2003; Figure 1). Warmer Antarctic conditions at 127 ka compared to 130,129 and 125 ka illustrate a remnant of the so-called overshoot, a millennial-scale Antarctic temperature peak occurring at the end of the penultimate deglaciation, and identified as a shorter excursion in GHG records (Figure 1). This overshoot is interpreted as a regional response of the bipolar seesaw mechanism (see discussion in Past-Interglacials-Working-Group-of-PAGES, 2016). 
Because of the overall dating uncertainties of paleoclimatic records (at least $2 \mathrm{ka}$ ) and the potential remaining fingerprint of millennial-scale dynamics around $127 \mathrm{ka}$, the $127 \mathrm{ka}$ data values should thus be treated with care for data-model comparison purpose of lig127k Tier 1 simulations. In particular, the excess warmth in Antarctica and more generally, the remnant of the millennial-scale bipolar seesaw imprint in paleo-records at 127 ka might not be simulated in the lig127k simulation solely forced by GHG and orbital forcing. However, additional Tier 2 sensitivity experiments will examine the impact of uncertainties in boundary conditions and in particular the role of cryosphere and ocean feedbacks in modulating the orbital forcing response (Otto-Bliesner et al., 2016). A specific Tier 2 sensitivity experiment will help disentangle the orbital vs. millennial-scale climatic variability by implementing in the baseline lig127k simulation a persistent freshwater flux of $0.2 \mathrm{~Sv}$ into the North Atlantic (details on the experiment design in Otto-Bliesner et al., 2016).

Also, potential delays in the response of specific components of the climate system (e.g. vegetation, deep ocean circulation) to the 127 ka radiative and GHG forcing may exist and these aspects require dedicated investigations. The transient behavior of the climate system will be investigated within PMIP4 with transient simulations to be run between 128 and $122 \mathrm{ka}$ (Otto-Bliesner et al., 2016). In addition to the multiple surface temperature time slices that now exist across the LIG, surface temperature time series are also available and provide a comprehensive data base for studying the transient climate evolution of the LIG (Capron et al., 2014; Hoffman et al., 2017).

\subsection{Comparison of the recent LIG surface temperature syntheses for the high-latitude regions}

Producing paleoclimate record syntheses to quantify LIG surface temperature changes is a longstanding goal in paleoclimate research (e.g. CLIMAP-project-members, 1984; CAPE-Last-Interglacial-ProjectMembers, 2006; Kaspar et al., 2005). Here, we focus on the four latest compilations (Turney and Jones, 2010; McKay et al., 2011; Capron et al., 2014; Hoffman et al., 2017; Figure 2) and provide an evaluation of their strengths and limitations (Table 2). First we discuss the similarities and differences in terms of temperature reconstructions at $127 \mathrm{ka}$ (Table 3) between the two LIG peak warmth-centered syntheses and our new 127 ka time slice (Section 4.1.1.). Second, we provide a more in-depth comparison between the recent Hoffman et al. (2017) synthesis and our 127 ka time slice (Section 4.1.2.). Finally, we provide guidance on the use of these various LIG compilations for future model-data comparisons in the framework of the CMIP6/PMIP4 127 ka experiments (Section 4.1.3.). 
interpreted as annual means and Greenland maximum warmth estimates should be considered with caution (Table 2). (4) Quantitative uncertainties integrating errors on age models, analysis and the calibration of microfossil transfer functions are not provided. The McKay et al. (2011) compilation focuses on the global ocean. Their global mean SST anomalies account for the errors attached to SST tracers, the seasonality of the SST records and for the limited spatial range of paleoclimatic records. However, their synthesis is also centered on the LIG peak warmth and deduced from SST records taken on their original timescales. Also, only a limited number of SST records is included for the high latitudes compared to the other syntheses (Figure 3). We now provide a comparison of the two peak warmth-centered compilations with our 127 ka time slice deduced from Capron et al. (2014). The compiled sites in McKay et al. (2011) do not exhibit the pronounced overall warmth in the North Atlantic observed in Turney and Jones (2010) and in our 127 ka time slice. In addition, the Turney and Jones (2010) synthesis does not illustrate the regional cooling prevailing in the Nordic Seas and in the West North Atlantic at $127 \mathrm{ka}$. In Table 4, we attempt to compare quantitatively the two peak warmth-centered compilations with the $127 \mathrm{ka}$ time-slice. Such an exercise is challenging mainly because (1) temperature records from different sites are included from one synthesis to the other and (2) different time-intervals are used as references for temperature anomaly calculations. We extract SST values from 13 marine sites that were included in Capron et al. (2014) and in either Turney and Jones (2010; four sites in common) or McKay et al. (2011; three sites in common), or in both syntheses (six sites in common between the three syntheses). For each site, we calculate the difference between the provided peak warmth anomaly value and the $127 \mathrm{ka}$ anomaly. To estimate the overall and regional degree of agreement of each of these peak-warmth syntheses with our $127 \mathrm{ka}$ time slice at these common sites we calculate the resulting Root Mean Standard Deviation (RMSD) considering 1) all sites, 2) the North Atlantic sites only and 3) the Southern Ocean sites only.

For a given site, the offset between the value extracted from Turney and Jones (2010) and the $127 \mathrm{ka}$ value varies between $-2.8^{\circ} \mathrm{C}$ and $+8.9^{\circ} \mathrm{C}$. When considering the 10 sites in common between Turney and Jones (2010) and our $127 \mathrm{ka}$ time slice, the RMSD is $3.4^{\circ} \mathrm{C}$. It is likely due to the fact that at $127 \mathrm{ka}$, peak warmth conditions are not systematically already reached in the North Atlantic region (the RMSD including only the

318 six North Atlantic sites is $4.0^{\circ} \mathrm{C}$ while the RMSD including the four Southern Ocean sites is $1.9^{\circ} \mathrm{C}$, see also 319 discussion in section 4.3). Note that we made the same calculation considering the $127 \mathrm{ka}$ values relative to the World Ocean Atlas 1998 instead of a preindustrial reference and the resulting North Atlantic RMSD is $3.2^{\circ} \mathrm{C}$ (not shown). As a result, the large offsets cannot be fully explained by the fact that the time interval of reference chosen for the two syntheses is different. For a given site, the difference between the value from McKay et al. (2011) and the $127 \mathrm{ka}$ value varies between $-2.2^{\circ} \mathrm{C}$ and $+3.9^{\circ} \mathrm{C}$. Overall, the discrepancies are reduced between the McKay et al. (2010) synthesis and our 127 ka time slice but they are still large especially in the North Atlantic region (total RMSD of $1.7^{\circ} \mathrm{C}$ based on nine sites and of $2.3^{\circ} \mathrm{C}$ when considering only the three North Atlantic sites). This comparison exercise is somewhat fictional since the Turney and Jones (2010) and McKay et al. (2011) do not represent any particular time interval across the LIG and instead a snapshot on the LIG peak warmth. Still, it enables to illustrate that these two peak warmth-centered syntheses do not 
represent robust data benchmarks in the North Atlantic and Southern Ocean regions in the framework on the CMIP6/PMIP4 127 ka simulations.

331

\subsubsection{Comparing our 127 ka time slice with the most recent Hoffman et al. (2017) compilation}

Recently, Hoffman et al. (2017) published a new LIG SST compilation of global extent and associated with a coherent temporal framework and quantitative estimates of the errors combining SST tracers and dating uncertainties (Table 2). Using the data provided in the Supplementary Online Material of Hoffman et al. (2017), we extracted a subset of their synthesis for the high latitudes at 127 ka following the methodology they used for building the 129, 125 and 120 ka time slices (Figure 3). Briefly we took for each core the SST value corresponding to the age $127 \mathrm{ka}$ on the mean 0.1-ka interpolated SST curve resulting from their Bayesian approach which integrates 1000 realizations of SST curves resulting from the propagation of uncertainties associated with age markers and the proxy-based SST calibrations. Surface temperature anomaly was then deduced by using the HadISST1.1 1870-1889 values provided in the supplementary material of Hoffman et al. (2017).

Overall, a comparable number of high-latitude SST records is included in Hoffman et al. (2017) and Capron et al. (2014) but the latter includes in addition polar surface air temperature records from ice cores. The two SST datasets are somehow complementary since Capron et al. (2014) provide mostly summer SST records (40 summer and two annual SST reconstructions) and Hoffman et al. (2017) gather 17 summer and 22 annual SST records. However differences in methodologies to define the common temporal framework and to estimate surface temperature changes prevent us to propose a $127 \mathrm{ka}$ time slice combining directly both syntheses (see further discussion below). The two syntheses have 12 summer SST records in common. The difference in site selection in both compilations likely arises from (1) different minimum temporal resolution cuts to select the SST records (2 ka in Capron et al. (2014) and 4 ka in Hoffman et al. (2017)) and (2) a climate alignment strategy in Hoffman et al. (2017) that requires benthic foraminifera $\delta^{18} 0$ record which might not systematically be available in some of the sites selected in Capron et al. (2014).

Both syntheses highlight the hemispheric asynchronous pattern in surface temperatures at the beginning of the LIG as observed in the 129 ka time slice from Hoffman et al. (2017) and the 130 ka time slice from Capron et al. (2014) (Figure 3). This observation further supports the crucial need for time-evolving syntheses across the LIG. We now provide a quantitative comparison of the 127 ka time slices inferred from Hoffman et al. (2017) and from our data synthesis following the same method as the method used to compare our 127 ka time slice with the ones from Turney and Jones (2010) and McKay et al. (2011) (Section 4.1.1, Table 3). Such a comparison is more straightforward in the present case since we are able here to use absolute surface temperature values given in the supplementary materials of Hoffmann et al. (2017) and Capron et al. (2014) so that the comparison is not affected by possible differences in preindustrial reference values. The resulting North Atlantic and Southern Ocean RMSD are of 1.2 and $0.8^{\circ} \mathrm{C}$ respectively. Overall, the resulting RMSD of $1.1^{\circ} \mathrm{C}$ based on 12 common SST records is much smaller than the RMSD values inferred 
when comparing our time slice with the LIG peak warmth syntheses and it is also within the range of stated quantitative $2 \sigma$ uncertainties for both syntheses.

Considering that Capron et al. (2014) and Hoffman et al. (2014) use the exact same original SST datasets on a depth scale for these selected sites, we interpret the temperature differences recorded at $127 \mathrm{ka}$ and ranging between 0.1 to $2.0^{\circ} \mathrm{C}$ for the different sites in Table 3 as resulting from three main factors. (1) Capron et al. (2014) use AICC2012 (Bazin et al., 2012; Veres et al., 2012) as the reference chronology while Hoffman et al. (2017) use the SpeleoAge time scale which results from the adjustment of the ice core EDC3 timescale using radiometric dates from Chinese speleothems (Barker et al., 2011). An offset of about 1 ka is observed between the two time scales around $127 \mathrm{ka}$, it increases through time reaching up to $3.4 \mathrm{ka}$ around 115 ka (Figure 4). (2) The definition of the tie points and associated relative uncertainty, which influence the determination of the final age model and thus the resulting $127 \mathrm{ka}$ temperature values, are different. (3) Despite a similar approach based on a Monte-Carlo analysis with 1000 age model realizations, the two studies do not use the same method of calculation to deduce the age model for each site, as well as quantitative estimates of associated uncertainties. The methodology of Hoffman et al. (2017) is based on Bayesian statistics (Haslett and Parnell, 2008) and results in a greater smoothing of the SST changes on an age scale compared to those inferred with our methodology based on linear interpolation between tie-points. This is illustrated in Figure 4 with a comparison of the resulting dated surface temperature records for the North Atlantic site EW9302-8JPC (Oppo et al., 1997; Oppo et al., 2001) that show an offset of $2^{\circ} \mathrm{C}$ at $127 \mathrm{ka}$. This exercise of comparison shows how critical age models, and the way they are defined, are in LIG data compilations. Using different SST interpolation and smoothing scheme also potentially leads to changes in the timing of the LIG maximum warmth and thus to changes in the estimated amplitude of the SST temperature change. As a result, the Capron et al. (2014) and Hoffman et al. (2017) climate syntheses cannot be merged unless a thorough work on harmonizing the chronologies of both compilations is carried out first.

\subsubsection{Recommendations}

Overall, we do not recommend the use of the peak warmth-centered syntheses from Turney and Jones (2010) and McKay et al. (2011) as benchmarks for the $127 \mathrm{ka}$ climate above polar ice sheets and at the surface of the North Atlantic and Southern Oceans in the CMIP6/PMIP4 127 ka simulations. For model-data comparison exercises focused on surface ocean changes at a global scale, a 127 ka time slice of global-scale inferred from the Hoffman et al. (2017) compilation should be favored over the McKay et al. (2011) synthesis changes at a global scale recorded in the ocean. For studies focusing on the high-latitudes regions, we recommend the use of the 127 ka time-slice based on the Capron et al. (2014) as it gather not only the largest number of SST records but also provide information about climatic changes above the polar ice sheets.

398 Finally, the surface temperature records included in Capron et al. (2014) and Hoffman et al. (2014) cannot be 399 combined in their current state.

\subsection{Regional and global surface temperature averages from LIG climate syntheses}


We discuss here new regional and existing global SST averages available across the LIG. While sitespecific estimates provide detailed information about the spatial structure of the changes, regional averages provide firs order estimate of mean responses across the LIG. Because of potential local bias affecting SST reconstructions and/or potential misrepresentation of processes at local scale in the CMIP6/PMIP4 models, they are particularly useful to evaluate models capability at a global and regional scale and also to benchmark models with reduced spatial resolution.

Because (1) air temperature estimates represent precipitation-weighed and annual signals for Greenland and Antarctica respectively, and (2) SST records are mostly interpreted as summer signals, we cannot propose a realistic $127 \mathrm{ka}$ high latitude average surface temperature encompassing all records in our data synthesis. Instead, we propose regional temperature anomalies for the North Atlantic, the Southern

412 Ocean (summer averages) and Antarctica (annual average) at 125, 127 and 130 ka (Table 1) based on records 413 on coherent chronologies and relative to preindustrial. We infer from the Capron et al. (2014) dataset that

414 North Atlantic and Southern Ocean summer averages were $+1.1^{\circ} \mathrm{C}\left(\mathrm{SE}: 0.7^{\circ} \mathrm{C}\right.$, based on 14 records $)$ and $+1.8^{\circ} \mathrm{C}$ (SE: $0.8^{\circ} \mathrm{C}$; based on 15 records) respectively at $127 \mathrm{ka}$. Following the same methodology, we infer also annual and summer North Atlantic and Southern Ocean averages based on the sites poleward $40^{\circ} \mathrm{N}$ and $40^{\circ} \mathrm{S}$ included in the Hoffman et al. (2017) datasets. 127 ka North Atlantic and Southern Ocean summer averages were $+1.9^{\circ} \mathrm{C}\left(\mathrm{SE}: 1.7^{\circ} \mathrm{C}\right.$, based on nine records) and $+1.6^{\circ} \mathrm{C}\left(\mathrm{SE}: 0.9^{\circ} \mathrm{C}\right.$, based on seven records) respectively while North Atlantic and Southern Ocean annual averages were $-0.2^{\circ} \mathrm{C}\left(\mathrm{SE}: 1.4^{\circ} \mathrm{C}\right.$, based on nine records) and $+2.7^{\circ} \mathrm{C}$ (SE: $1.0^{\circ} \mathrm{C}$, based on 12 records, see footnote of Table 1 regarding this annual average). Despite existing surface temperature differences observed at 127 ka for a given site included in both compilations (c.f. section 4.1.2, Table 2), the North Atlantic and Southern Ocean regional summer averages from the two compilations based on different methodologies to infer a common chronological framework are overall consistent within their stated uncertainties. Combining the annual and summer averages represents useful quantitative information to evaluate (1) the seasonality of climate models in the high-latitude regions and (2) the sensitivity to the high-latitude summer warmth of the polar ice sheets whose melting caused a 6-9m global sea level rise.

The warming at $127 \mathrm{ka}$ relative to preindustrial is greater over polar ice sheets (e.g. $+2.2^{\circ} \mathrm{C}$ with SE: $1.4^{\circ} \mathrm{C}$ above Antarctica) compared to the surface layer of the Southern Ocean and the North Atlantic. First, it likely originates from the fact that land areas on average change more rapidly than the ocean (land-sea contrast; e.g. Joshi et al., 2008; Braconnot et al., 2012). Second, it also arises from the polar amplification of surface warming (e.g. Holland and Bitz, 2003; Masson-Delmotte et al., 2006) due to feedbacks related to surface albedo because of changes in land ice and sea ice cover, to ice sheet elevation and to atmospheric processes such as changes in cloud cover (and cloud radiative feedbacks, e.g. Curry et al., 1996) and variations in heat advection (Alexeev et al., 2005).

Finally, Hoffman et al. (2017) estimate that global annual SST were only $0.5 \pm 0.3^{\circ} \mathrm{C}$ warmer-thanpreindustrial at $125 \mathrm{ka}$ and a similar value is inferred at $127 \mathrm{ka}$ based on their time-evolving global stack 438 (Supplementary Online Material from Hoffman et al., 2017). In contrast, the high-latitude summer warming 
was at least $1.1\left(\mathrm{SE}: 0.7^{\circ} \mathrm{C}\right)$ and $1.6\left(\mathrm{SE}: 0.9^{\circ} \mathrm{C}\right)$ warmer-than-preindustrial in the North Atlantic and the to preindustrial conditions is compensated globally because of other regions affected by surface changes of smaller amplitude, i.e. the low-latitude SST records gathered in Hoffman et al. (2017) point toward an annual average SST in the tropics (between $23.5^{\circ} \mathrm{N}$ and $\left.23.5^{\circ} \mathrm{S}\right)$ slightly below the preindustrial mean at 127 ka $(-0.1$ $\pm 0.4^{\circ} \mathrm{C}$ as inferred from Supplementary Online Material from Hoffman et al., 2017). Overall, these results emphasize the existence of considerable regional and seasonal differences in the amplitude of surface temperature changes at $127 \mathrm{ka}$, and in particular the large response of the high-latitude regions compared to global ocean surface conditions only slightly warmer than preindustrial.

\section{Summary and outlook}

Based on the Capron et al. (2014) compilation, we produce a 127 ka surface temperature time slice relative to preindustrial showing warmer-than-preindustrial conditions in the high latitudes (Table 1; Figure 2). Because at $127 \mathrm{ka}$, (1) the warmest time period can be reconstructed when considering the two high latitude regions and (2) large millennial-scale climate shifts are limited (Figure 1), it represents the most suitable time interval to run the CMIP5/PMIP4 LIG Tier 1 and Tier 2 simulations. Differences in the climatic patterns observed between the $127 \mathrm{ka}, 125$ and 130 ka time slices inferred from the Capron et al. (2014) synthesis (and also observed between the 127, 125 and 129 ka time slices inferred from the Hoffman et al. (2017) synthesis) strengthen the need to benchmark the Tier 1 and Tier 2 climate snapshot simulations with data from the appropriate 127 ka time interval.

We provide an in-depth evaluation of existing LIG climate syntheses and guidance for using them to evaluate climate model simulations. Due to their chronological limitations and their focus on the LIG peak warmth only, we do not recommend the use of the syntheses of Turney and Jones (2010) and McKay et al. (2011) as benchmarks for the CMIP6/PMIP4 127 ka simulations performed in the high-latitude regions. We recommend instead using the new 127 ka surface temperature dataset. Associated with summer SST

464 reconstructions, it will be particularly useful to evaluate data-model temperature differences seasonally in

465 the context of a large summer insolation forcing in the North Hemisphere. Site-specific estimates provide

466 detailed information about the spatial structure of the changes and the regional averages provide first-order estimates of mean responses at $127 \mathrm{ka}$.

The Turney and Jones (2010) compilation is the only one including continental records. Thus, the fact that it does not represent any specific nor realistic time window should be kept in mind when using it for model-data comparison exercises over land or when using as a benchmark its global annual surface

472 represents currently the only global ocean synthesis associated with harmonized chronologies extending to

473 the low latitude annual ocean surface temperatures and it should be favored over the McKay et al. (2011)

474 synthesis when investigating LIG SST changes at a global scale. 
It is common practice to evaluate simulations of present-day climate to multiple observation datasets considered independently because of different blending methods and assimilation systems. In the same way and because of the use of different reference chronologies and methodologies to infer temporal surface temperature changes, the Capron et al. (2014) and Hoffman et al. (2017) datasets should not be combined as such but, instead, treated as independent data benchmarks. Overall, our critical evaluation of available climate syntheses for benchmarking upcoming CMIP6/PMIP4 LIG simulations at 127 ka calls for the urgent need to develop millennial-scale transient climate syntheses of global extent, integrating ice, marine and continental records in a coherent temporal framework accounting for age and tracer uncertainties. In addition, future syntheses should also extend temperature synthesis to additional parameters such as deep ocean circulation changes and sea ice extent.

The LIG is not a direct analogue to future climate due to differences in the primary forcing of the warming i.e. caused by larger boreal summer insolation forcing, and not from enhanced greenhouse gas concentrations. However, the recent quantitative regional reconstructions indicate a warmth in the polar and sub-polar regions of similar amplitudes to the ones that might be reached by 2100 , in particular in the context of climate policies that would limit global warming to $+1.5^{\circ} \mathrm{C}$ compared to a preindustrial background state. This leaves the LIG as a particularly relevant target for understanding mechanisms and feedbacks at play, and the polar ice sheet response to such high-latitude warmer climate.

Acknowledgments: We are grateful to members of the PAGES/PMIP Working Group on Quaternary Interglacials (QUIGS) and we thank in particular all participants of the Warm Extremes Workshop (November, 9-12 th 2015, Cambridge, UK) for stimulating discussions. We also thank Anaïs Orsi for useful discussions regarding ice core temperature reconstructions. This work is a contribution to the PAGES/PMIP Working Group on Quaternary Interglacials (QUIGS). E. C. is funded by the European Union's Seventh Framework Programme for research and innovation under the Marie Skłodowska-Curie grant agreement no 600207. B. L. O-B is supported by the U.S. National Science Foundation (NSF) sponsorship of NCAR. R. F. acknowledges the funding of the NSF Arctic System Science. E.W.W. is supported by the Royal Society. This is LSCE contribution $n^{\circ} \mathrm{XX}$.

\section{References:}

Alexeev, V.A., Langen, P.L., Bates, J.R., 2005. Polar amplification of surface warming on an aquaplanet in "ghost forcing" experiments without sea ice feedbacks. Climate Dynamics 24, 655-666.

Bakker, P., Stone, E.J., Charbit, S., Chroger, M., Krebs-Kanzow, U., Ritz, S.P., Varma, V., Khon, V., Lunt, D.J., Mikolajewicz, U., Prange, M., Renssen, H., Schneider, B., Schulz, M., 2013. Last interglacial temperature evolution - a model inter-comparison. Climate of the past 9, 605-619. 
Barker, S., Knorr, G., Edwards, R.L., Parrenin, F., Putnam, A.E., Skinner, L.C., Wolff, E., Ziegler, M., 2011. 800,000 Years of Abrupt Climate Variability. Science 334, 347-351.

Bauch, H.A., Erlenkeuser, H., 2008. A "critical" climatic evaluation of last interglacial (MIS 5e) records from the Norwegian Sea. Polar Research 27, 135-151.

Bazin, L., Landais, A., Lemieux-Dudon, B., Toyé Mahamadou Kele, H., Veres, D., Parrenin, F., Martinerie, P., Ritz, C., Capron, E., Lipenkov, V., Loutre, M.-F., Raynaud, D., Vinther, B., Svensson, A., Rasmussen, S.O., Severi, M., Blunier, T., Leuenberger, M., Fischer, H., Masson-Delmotte, V., Chappellaz, J., Wolff, E.W., 2013. An optimized multi-proxy, multi-site Antarctic ice and gas orbital chronology (AICC2012): 120-800 ka. Climate of the Past 9, 1715-1731.

Braconnot, P., Harrison, S.P., Kageyama1, Bartlein, P.J., Masson-Delmotte, V., Abe-Ouchi, A., Otto-Bliesner, B., Zhao, Y., 2012. Evaluation of climate models using palaeoclimatic data. Nature Climate Change DOI: 10.1038/NCLIMATE1456.

Broecker, W.S., 1998. Paleocean circulation during the Last Deglaciation: A bipolar seesaw? Paleoceanography 13, DOI - 10.1029/1097PA03707.

CAPE-Last-Interglacial-Project-Members, 2006. Last Interglacial Arctic warmth confirms polar amplification of climate change. Quaternary Science Reviews 25, 1383-1400.

Capron, E., Govin, A., Stone, E.J., Masson-Delmotte, V., Mulitza, S., Otto-Bliesner, B., Sime, L., Waelbroeck, C., Wolff, E., 2014. Temporal and spatial structure of multi-millennial temperature changes at high latitudes during the Last Interglacial. Quaternary Science Reviews, doi: 10.1016/j.quascirev.2014.1008.1018.

CLIMAP-project-members, 1984. The Last Interglacial Ocean. Quaternary Research 21, 123-224.

Cortese, G., Abelmann, A., Gersonde, R., 2007. The last five glacial-interglacial transitions: A high-resolution 450,000-year record from the subantarctic Atlantic. Paleoceanography 22, PA4203.

Curry, J.A., Rossow, W.B., Randall, D., Schramm, J.L., 1996. Overview of Arctic cloud and radiation characteristics. Journal of climate 9, 1731- 1764.

DeConto, R.M., Pollard, D., 2016. Contribution of Antarctica to past and future sea-level rise. Nature 531, 591597.

Dutton, A., Carlson, A.E., Long, A.J., Milne, G.A., Clark, P.U., DeConto, R., Horton, B.P., Rahmstorf, S., Raymo, M.E., 2015. Sea-level rise due to polar ice-sheet mass loss during past warm periods. Science 349.

Goelzer, H., Huybrechts, P., Loutre, M.F., Fichefet, T., 2016. Impact of ice sheet meltwater fluxes on the climate evolution at the onset of the Last Interglacial. Clim. Past 12, 1721-1737.

Govin, A., Braconnot, P., Capron, E., Cortijo, E., Duplessy, J.-C., Jansen, E., Labeyrie, L., 2012. Persistent influence of ice sheet melting on high northern latitude climate during the early Last Interglacial. Climate of the Past 8, 483-507, doi:410.5194/cp-5198-5483-2012. 

Bassinot, F., Bazin, L., Blunier, T., Combourieu-Nebout, N., El Ouahabi, A., Genty, D., Gersonde, R., Jimenez-

544 Amat, P., Landais, A., Martrat, B., Masson-Delmotte V., Parrenin, F., Seidenkrantz, M.-S., Veres, D., Waelbroeck, 545 C., Zahn, R., 2015. Sequence of events from the onset to the demise of the Last Interglacial: Evaluating 546 strengths and limitations of chronologies used in climatic archives. Quaternary Science Reviews 129, 1-36.

547 Hartmann, D.L., Klein Tank, A.M.G., Rusticucci, M., Alexander, L., Brönnimann, S., Charabi, Y., Dentener, F., 548 Dlugokencky, E., Easterling, D., Kaplan, A., Soden, B., Thorne, P., Wild, M., Zhai, P.M., 2013. Observations: 549 Atmosphere and Surface. In: Climate Change 2013: The Physical Science Basis. Contribution of Working 550 Group I to the Fifth Assessment Report of the Intergovernmental Panel on Climate Change [Stocker, T.F., D.

551 Qin, G.-K. Plattner, M. Tignor, S.K. Allen, J. Boschung, A. Nauels, Y. Xia, V. Bex and P.M. Midgley (eds.)].

552 Haslett, J., Parnell, A., 2008. A simple monotone process with application to radiocarbon-dated depth 553 chronologies. J.R. Stat. Soc. 57, 399-418. doi:310.1111/j.1467-9876.2008.00623.x. Hoffman, J.S., Clark, P.U., Parnell, A.C., He, F., 2017. Regional and global sea-surface temperatures during the 555 last interglaciation. Science 355, 276-279.

556 Holland, M.M., Bitz, C.M., 2003. Polar amplification of climate change in coupled models. Climate Dynamics 21, $557 \quad 221-232$.

558 Joshi, M.M., Gregory, J.M., Webb, M.J., Sexton, D.M.H., Johns, T.C., 2008. Mechanisms for the land/sea warming contrast exhibited by simulations of climate change. Clim Dyn (2008) 30, 455-465.

560 Jouzel, J., Masson-Delmotte, V., Cattani, O., Dreyfus, G., Falourd, S., Hoffmann, G., Minster, B., Nouet, J., Barnola, 561 J.-M., Fisher, H., Gallet, J.-C., Johnsen, S., Leuenberger, M., Loulergue, L., Luethi, D., Oerter, H., Parrenin, F., 562 Raisbeck, G., Raynaud, D., Schilt, A., Schwander, J., Selmo, J., Souchez, R., Spahni, R., Stauffer, B., Steffensen, J.P., 563 Stenni, B., Stocker, T.F., Tison, J.-L., Werner, M., Wolff, E.W., 2007. Orbital and millennial Antarctic climate 564 variability over the past 800,000 years. Science $317,793-796$.

565 Kageyama, M., Albani, S., Braconnot, P., Harrison, S.P., Hopcroft, P.O., Ivanovic, R.F., Lambert, F., Marti, O., 566 Peltier, W.R., Peterschmitt, J.Y., Roche, D.M., Tarasov, L., Zhang, X., Brady, E.C., Haywood, A.M., LeGrande, A.N., 567 Lunt, D.J., Mahowald, N.M., Mikolajewicz, U., Nisancioglu, K.H., Otto-Bliesner, B.L., Renssen, H., Tomas, R.A., 568 Zhang, Q., Abe-Ouchi, A., Bartlein, P.J., Cao, J., Lohmann, G., Ohgaito, R., Shi, X., Volodin, E., Yoshida, K., Zhang, X., 569 Zheng, W., 2017. The PMIP4 contribution to CMIP6 - Part 4: Scientific objectives and experimental design of 570 the PMIP4-CMIP6 Last Glacial Maximum experiments and PMIP4 sensitivity experiments. Geosci. Model Dev. 571 Discuss. 2017, 1-33.

572 Kaspar, F., Kuhl, N., Cubasch, U., Litt, T., 2005. A model-data comparison of European temperatures in the 573 Eemian interglacial. Geophys. Res. Letters, DOI:10.1029/2005GL022456. 

Fischer, H., Orsi, A., Prié, F., Vinther, B., Dahl-Jensen, D., 2016. How warm was Greenland during the last interglacial period? Clim. Past Discuss. 2016, 1-27.

577 Loulergue, L., Schilt, A., Spahni, R., Masson-Delmotte, V., Blunier, T., Lemieux, B., Barnola, J.M., Raynaud, D., 578 Stocker, T.F., Chappellaz, J., 2008. Orbital and millennial-scale features of atmospheric $\mathrm{CH}_{4}$ over the past 579800,000 years. Nature 453, 383-386. Loutre, M.F., Fichefet, T., Goosse, H., Huybrechts, P., Goelzer, H., Capron, E., 2014. Factors controlling the last interglacial climate as simulated by LOVECLIM1.3. Clim. Past 10, 1541-1565.

582 Lunt, D.J., A. Abe-Ouchi, A., Bakker, P., Berger, A., Braconnot, P., Charbit, S., Fischer, N., Herold, N., Jungclaus, 583 J.H., Khon, V.C., Krebs-Kanzow, U., Langebroek, P.M., Lohmann, G., Nisancioglu, K.H., Otto-Bliesner, B.L., Park, 584 W., Pfeiffer, M., Phipps, S.J., Prange, M., Rachmayani, R., Renssen, H., Rosenbloom, N., Schneider, B., Stone, E.J., 585 Takahashi, E., Wei, W., Yin, Q., Zang, Z.S., 2013. A multi-model assessment of last interglacial temperatures. Climate of the past 9, 699-717.

587 Lüthi, D., Le Floch, M., Bereiter, B., Blunier, T., Barnola, J.-M., Siegenthaler, U., Raynaud, D., Jouzel, J., Fischer, H., 588 Kawamura, K., Stocker, T.F., 2008. High-resolution carbon dioxide concentration record 650,000-800,000 589 years before present. Nature 453, 379-382.

590 Marino, G., Rohling, E.J., Rodriguez-Sanz, L., Grant, K.M., Heslop, D., Roberts, A.P., Stanford, J.D., Yu, J., 2015. 591 Bipolar seesaw control on last interglacial sea level. Nature 522, 197-201.

592 Masson-Delmotte, V., Kageyama, M., Braconnot, P., Charbit, S., Krinner, G., Ritz, C., Guilyardi, E., Jouzel, J., Abe593 Ouchi, A., Crucifix, M., Gladstone, R.M., Hewitt, C.D., Kitoh, A., Legrande, A., Marti, O., Merkel, U., Motoi, T., 594 Ohgaito, R., Otto-Bliesner, B., Peltier, W.R., Ross, I., Valdes, P.J., Vettoretti, G., Weber, S.L., Wolk, F., 2006. Past 595 and future polar amplification of climate change: climate model intercomparisons and ice-core constraints. 596 Climate Dynamics 0930-7575.

597 Masson-Delmotte, V., Schulz, M., Abe-Ouchi, A., Beer, J., Ganopolski, A., Gonzalez, Rouco, J.F., Jansen, E., 598 Lambeck, K., Luterbacher, J., Naish, T., Osborn, T., Otto-Bliesner, B., Quinn, T., Ramesh, R., Rojas, M., Shao, X., 599 Timmermann, A., 2013. Information from paleoclimate archives. . In: Stocker, T.F., Qin, D., Plattner, G.-K., 600 Tignor, M., Allen, S.K., Boschung, J., Nauels, A., Xia, Y., Bex, V., Midgley, P.M. (Eds.), Climate Change 2013: the 601 Physical Science Basis. Contribution of Working Group I to the Fifth Assessment Report of the 602 Intergovernmental Panel on Climate Change. Cambridge University Press, Cambridge, United Kingdom and 603 New York, NY, USA, pp. 383-464 (Chapter 5).

604 Masson-Delmotte, V., Steen-Larsen, H.C., Ortega, P., Swingedouw, D., Popp, T., Vinther, B.M., Oerter, H., 605 Sveinbjornsdottir, A.E., Gudlaugsdottir, H., Box, J.E., Falourd, S., Fettweis, X., Gallée, H., Garnier, E., Gkinis, V., 606 Jouzel, J., Landais, A., Minster, B., Paradis, N., Orsi, A., Risi, C., Werner, M., White, J.W.C., 2015. Recent changes 
607 in north-west Greenland climate documented by NEEM shallow ice core data and simulations, and 608 implications for past-temperature reconstructions. The Cryosphere 9, 1481-1504.

609 Masson-Delmotte, V., Stenni, B., Blunier, T., Cattani, O., Chappellaz, J., Cheng, H., Dreyfus, G., Edwards, R.L., 610 Falourd, S., Govin, A., Kawamura, K., Johnsen, S.J., Jouzel, J., Landais, A., Lemieux-Dudon, B., Lourantou, A., 611 Marshall, G., Minster, B., Mudelsee, M., Pol, K., Röthlisberger, R., Selmo, E., Waelbroeck, C., 2010. Abrupt 612 change of Antarctic moisture origin at the end of Termination II. Proceedings of the National Academy of 613 Sciences, doi: 10.1073/pnas.0914536107.

614 McKay, N.P., Overpeck, J.T., Otto-Bliesner, B.L., 2011. The role of ocean thermal expansion in Last Interglacial 615 sea level rise. Geophys. Res. Letters 38, DOI:10.1029/2011GL048280.

616 NEEM-community-members, 2013. Eemian interglacial reconstructed from a Greenland folded ice core. 617 Nature 493, 489-493, doi:410.1038/nature11789.

618 Oppo, D.W., Horowitz, M., Lehman, S.J., 1997. Marine core evidence for reduced deep water production during 619 Termination II followed by a relatively stable substage 5e (Eemian). Paleoceanography 12, 51-63, doi: 620 10.1029/1096PA03133.

621 Oppo, D.W., Keigwin, L.D., McManus, J.F., Cullen, J.L., 2001. Persistent suborbital climate variability in marine 622 isotope stage 5 and Termination II. Paleoceanography 16, 280-292.

623 Oppo, D.W., McManus, J.F., Cullen, J.L., 2006. Evolution and demise of the Last Interglacial warmth in the 624 subpolar North Atlantic. Quaternary Science Reviews 25(23-24), 3268-3277, 625 doi:3210.1016/j.quascirev.2006.3207.3006.

626 Otto-Bliesner, B., Rosenbloom, N., Stone, E., McKay, N.P., Lunt, D.J., Brady, E.C., Overpeck, J.T., 2013. How warm 627 was the Last Interglacial? New model-data comparisons. Philos Trans A Math Phys Eng Sci, doi: $62810.1098 /$ rsta.2013.0097.

629 Otto-Bliesner, B.L., Braconnot, P., Harrison, S.P., Lunt, D.J., Abe-Ouchi, A., Albani, S., Bartlein, P.J., Capron, E., 630 Carlson, A.E., Dutton, A., Fischer, H., Goelzer, H., Govin, A., Haywood, A., Joos, F., Legrande, A.N., Lipscomb, 631 W.H., Lohmann, G., Mahowald, N., Nehrbass-Ahles, C., Pausata, F.S.R., Peterschmitt, J.Y., Phipps, S., Renssen, H., 632 2016. The PMIP4 contribution to CMIP6 - Part 2: Two Interglacials, Scientific Objective and Experimental 633 Design for Holocene and Last Interglacial Simulations. Geosci. Model Dev. Discuss. 2016, 1-36.

634 Past-Interglacials-Working-Group-of-PAGES, 2016. Interglacials of the last 800,000 years. Reviews of 635 Geophysics doi:10.1002/2015RG000482.

636 Pfeiffer, M., Lohmann, G., 2016. Greenland Ice Sheet influence on Last Interglacial climate: global sensitivity 637 studies performed with an atmosphere-ocean general circulation model. Clim. Past 12, 1313-1338. 

nineteenth century. J. Geophys. Res. 108, 4407, doi:4410.1029/2002JD002670.

641 Schmidt, G.A., Annan, J.D., Bartlein, P.J., Cook, B.I., Guilyardi, E., Hargreaves, J.C., Harrison, S.P., Kageyama, M.,

642 LeGrande, A.N., Konecky, B., Lovejoy, S., Mann, M.E., Masson-Delmotte, V., Risi, C., Thompson, D.,

643 Timmermann, A., Tremblay, L.B., Yiou, P., 2014. Using palaeo-climate comparisons to constrain future 644 projections in CMIP5. Clim. Past 10, 221-250.

645

646

647

Sgubin, G., Swingedouw, D., Drijfhout, S., Mary, Y., Bennabi, A., 2017. Abrupt cooling over the North Atlantic in modern climate models. Nature Communications 8.

Stocker, T.F., Johnsen, S.J., 2003. A minimum thermodynamic model for the bipolar seesaw. Paleoceanography $18,1087$.

Stone, E.J., Capron, E., Lunt, D.J., Payne, A.J., Singarayer, J.S., Valdes, P.J., Wolff, E.W., 2016. Impact of melt water on high latitude early Last Interglacial climate. Climate of the Past 12, 1919-1932.

Turney, C.S.M., Jones, R.T., 2010. Does the Agulhas Current amplify global temperatures during superinterglacials? Journal of Quaternary Science 25(6), 839-843.

Uemura, R., Masson-Delmotte, V., Jouzel, J., Landais, A., Motoyama, H., Stenni, B., 2012. Ranges of moisturesource temperature estimated from Antarctic ice cores stable isotope records over glacial-interglacial cycles. Clim. Past 8, 1109-1125.

Vaughan, D.G., Comiso, J.C., Allison, I., Carrasco, J., Kaser, G., Kwok, R., Mote, P., Murray, T., Paul, F., Ren, J., Rignot, E., Solomina, O., Steffen, K., Zhang, T., 2013. Observations: Cryosphere. In: Climate Change 2013: The Physical Science Basis, Contribution ofWorking Group I to the Fifth Assessment Report of the Intergovernmental Panel on Climate Change, edited by: Stocker, T. F., Qin, D., Plattner, G.-K., Tignor, M., Allen, S.

K., Boschung, J., Nauels, A., Xia, Y., Bex, V., and Midgley, P. M., Cambridge University Press, Cambridge, United Kingdom and New York, NY, USA.

Veres, D., Bazin, L., Landais, A., Toyé Mahamadou Kele, H., Lemieux-Dudon, B., Parrenin, F., Martinerie, P., Blayo, E., Blunier, T., Capron, E., Chappellaz, J., Rasmussen, S.O., Severi, M., Svensson, A., Vinther, B., Wolff, E.W., 2013. The Antarctic ice core chronology (AICC2012): an optimized multi-parameter and multi-site dating approach for the last 120 thousand years. 9, 1733-1748, doi:1710.5194/cp-1739-1733-2013.

WCRP-Coupled-Model-Intercomparison-Project-Phase-5, 2011. CLIVAR Exchanges Newsletter special issue no 56,16 , no 2 .

Wunch, 2002. What is the thermohaline circulation? Science 298, 1179-1180. 
Table 1. 130, 127 and 125 ka regional surface temperature changes deduced from the Capron et al. (2014) datasets and 129, 127 and 125 ka regional surface temperature changes deduced from the Hoffman et al. (2017) datasets. Area-weighted average summer (or annual) SST values, calculated for the North Atlantic and the Southern Ocean sectors and area-weighted annual air temperature values calculated for the Antarctic sector are indicated in bold. For each case, the associated standard error $(2 \sigma)$ ranging 0.5 to $1.7^{\circ} \mathrm{C}$ is given in italics. The number of records considered for the calculation for each sector and each time slice is indicated in brackets. A value and associated mean squared error is also given for regional surface temperature differences between the (1) 127 and 130 ka and (2) 125 and 127 ka from the Capron et al. (2014) datasets. Details on the calculation methodology are provided in the Supplementary Material.

\begin{tabular}{|c|c|c|c|c|c|c|c|}
\hline & Sector & 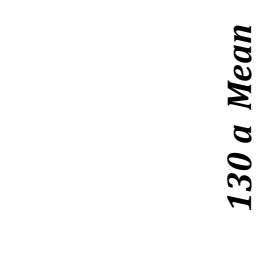 & 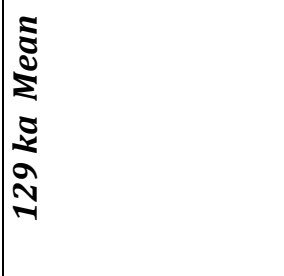 & 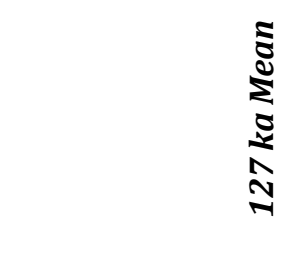 & 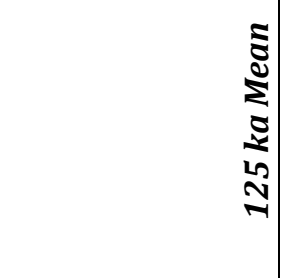 & 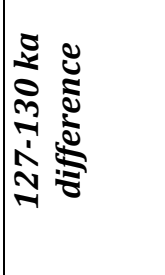 & 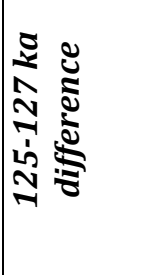 \\
\hline \multirow[t]{3}{*}{ Capron et al. 2014 * } & N. Atl. Summer SST & $-4.2 \pm 0.8(13)$ & $\mathbf{N} / \mathbf{A}$ & $1.1 \pm 0.7(14)$ & $1.2 \pm 0.7(14)$ & $5.3 \pm 1.0$ & $0.1 \pm 1.0$ \\
\hline & S. Ocean Summer SST & $1.8 \pm 0.9(15)$ & $\mathbf{N} / \mathbf{A}$ & $1.8 \pm 0.8(15)$ & $1.6 \pm 0.8(15)$ & $\mathbf{0 . 1} \pm 1.2$ & $-0.3 \pm 1.2$ \\
\hline & Ant. Ann. Air Temp. & $1.9 \pm 1.4(4)$ & N/A & $2.2 \pm 1.4(4)$ & $\mathbf{1 . 3} \pm 1.4(4)$ & $0.3 \pm 2.0$ & $-0.9 \pm 2.0$ \\
\hline \multirow[t]{4}{*}{ Hoffman et al. 2017} & N. Atl. Summer SST & N/A & $-\mathbf{0 . 8} \pm 1.7(9)$ & $1.9 \pm 1.7(9)$ & $2.7 \pm 1.2(9)$ & N/A & $\mathbf{N} / \mathbf{A}$ \\
\hline & N. Atl. Annual SST & $\mathbf{N} / \mathbf{A}$ & $-3.0 \pm 1.6(9)$ & $-0.2 \pm 1.4(9)$ & $0.8 \pm 1.0(9)$ & N/A & $\mathbf{N} / \mathbf{A}$ \\
\hline & S. Ocean Summer SST & $\mathbf{N} / \mathbf{A}$ & $1.8 \pm 1.0(7)$ & $1.6 \pm 0.9(7)$ & $1.3 \pm 1.0(7)$ & N/A & $\mathbf{N} / \mathbf{A}$ \\
\hline & S. Ocean Annual SST & $\mathbf{N} / \mathbf{A}$ & $2.7 \pm 1.0(12) * *$ & $2.7 \pm 1.0(12) * *$ & $2.7 \pm 1.1(12)^{* *}$ & N/A & $\mathbf{N} / \mathbf{A}$ \\
\hline
\end{tabular}

* Note that only marine sediment core records for which SST records are interpreted as summer signals are included in calculations from the Capron et al. (2014) datasets. It results in considering all marine records (sites shown on Figure 2) except the DSDP-594 temperature record from the Southern Ocean which is interpreted as an annual signal. All annual surface temperature reconstructions from the Antarctic ice core sites represented on Figure 2 have been included ( 4 records).

** The Southern Ocean Annual SST average is anomalously high considering the Southern Ocean summer average $\left(1.8 \pm 0.9^{\circ} \mathrm{C}\right)$. This is likely due to high SST anomalies calculated for cores ODP-1089, MD97-2121 and MD97-2120. For those three cores, HadISST preindustrial values are particularly low compared to core top SST estimates, which could explain the high SST anomalies reconstructed at these sites. 
Table 2. Strengths and limitations of the four most recent LIG surface temperature compilations (Turney and Jones, 2010; McKay et al., 2011; Capron et

\begin{tabular}{|c|c|c|c|c|c|c|c|}
\hline & 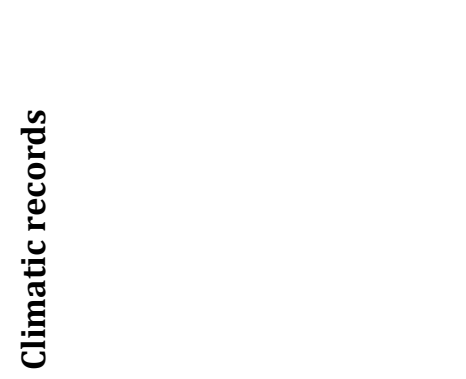 & 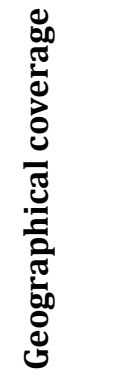 & 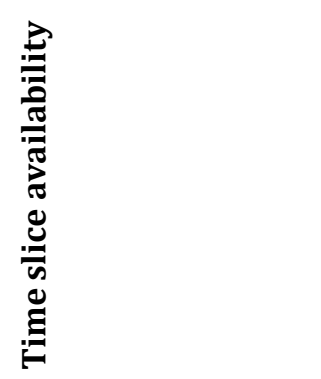 & 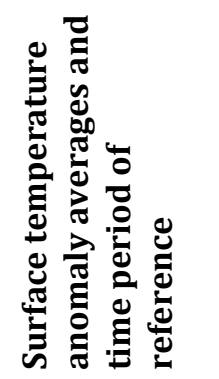 & 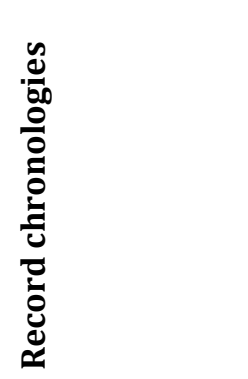 & 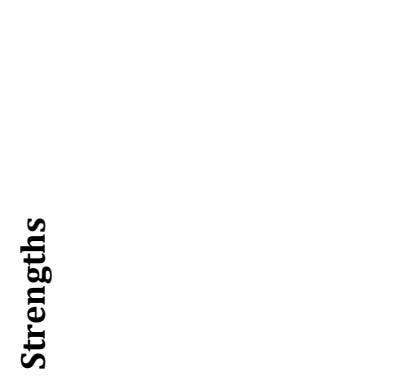 & \\
\hline 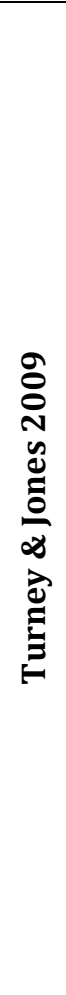 & $\begin{array}{l}\text { - } 263 \text { surface temperature } \\
\text { records interpreted as annual } \\
\text { signals; } \\
\text { - SST from marine sediment } \\
\text { cores based on } \mathrm{Sr} / \mathrm{Ca} \text {, } \\
\text { unsaturated alkenone and } \\
\mathrm{Mg} / \text { Ca ratios, diatom and } \\
\text { radiolarian transfer functions; } \\
\text { - Surface air temperatures } \\
\text { from polar ice cores based on } \\
\text { water stable isotopes; } \\
\text { - Surface air temperatures } \\
\text { from terrestrial records based } \\
\text { on pollen, macrofossil, } \\
\text { coleptera. }\end{array}$ & Global & $\begin{array}{l}\text { - } 1 \text { map centered on } \\
\text { LIG peak warmth: } \\
\rightarrow \text { Average across } \\
\text { the benthic } \delta^{18} \mathrm{O} \\
\text { plateau for marine } \\
\text { records; } \\
\rightarrow \text { Average across } \\
\text { the ice } \delta^{18} 0 \text { plateau } \\
\text { for ice records; } \\
\rightarrow \text { Average across } \\
\text { "the period of } \\
\text { maximum warmth" } \\
\text { for terrestrial } \\
\text { records. }\end{array}$ & $\begin{array}{l}\text { Peak warmth } \\
\text { global annual } \\
\text { average: } \\
\bullet+1.5 \pm 0.1^{\circ} \mathrm{C} \\
\text { compared to } \\
1961-1990) ; \\
\bullet \sim+1.9^{\circ} \mathrm{C} \\
\text { compared to } \\
\text { preindustrial }\end{array}$ & $\begin{array}{l}\text { - Chronologies } \\
\text { kept as in } \\
\text { original } \\
\text { publications of } \\
\text { the records. }\end{array}$ & $\begin{array}{l}\text { - Global extent; } \\
\text { - Largest spatial } \\
\text { coverage; } \\
\text { - Continental records are } \\
\text { included. }\end{array}$ & $\begin{array}{l}\text { - No harmonized } \\
\text { chronologies between } \\
\text { records; } \\
\text { - Peak-warmth centered } \\
\text { map is not representative } \\
\text { of any specific LIG time } \\
\text { interval; } \\
\text { - Global average not } \\
\text { corrected for spatial } \\
\text { coverage; } \\
\text { - All SST records } \\
\text { considered as annual } \\
\text { signals; } \\
\text { - Large uncertainties on } \\
\text { Greenland maximum } \\
\text { warmth estimates* } \\
\text { - Lack of information on: } \\
\rightarrow \text { systematic } \\
\text { quantitative surface } \\
\text { temperature uncertainty } \\
\text { estimates; } \\
\rightarrow \text { Calculation } \\
\text { methodology of the global } \\
\text { temperature average. }\end{array}$ \\
\hline
\end{tabular}




\begin{tabular}{|c|c|c|c|c|c|c|c|}
\hline 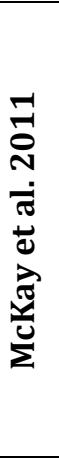 & $\begin{array}{l}\text { - } 76 \text { SST from marine } \\
\text { sediment cores }(\mathrm{Mg} / \text { Ca ratios } \\
\text { in foraminifera, alkenone } \\
\text { unsaturation ratios and faunal } \\
\text { assemblage transfer functions } \\
\text { (for radiolaria, foraminifera, } \\
\text { diatoms and coccoliths); } \\
\text { - Annual and summer SST } \\
\text { signals; } \\
\text { - Temporal resolution cut: < } \\
\text { 3ka. }\end{array}$ & $\begin{array}{l}\text { Global } \\
\text { ocean }\end{array}$ & $\begin{array}{l}\text { - } 1 \text { map centered on } \\
\text { LIG peak warmth } \\
\text { calculated as the } \\
\text { average SST of a } 5 \\
\text { kyr period centered } \\
\text { on the warmest } \\
\text { temperature } \\
\text { between } 135 \text { and } \\
118 \text { ka. }\end{array}$ & $\begin{array}{l}\text { - Peak LIG global } \\
\text { SST: }+0.7 \pm 0.6^{\circ} \mathrm{C} \\
\text { compared to late } \\
\text { Holocene. }\end{array}$ & $\begin{array}{l}\text { - Chronologies } \\
\text { kept as in } \\
\text { original } \\
\text { publications of } \\
\text { the records. }\end{array}$ & $\begin{array}{l}\text { - Global ocean extent; } \\
\text { - Global averages are } \\
\text { ocean area-weighted (i.e. } \\
\text { accounting for data } \\
\text { sparseness) }\end{array}$ & $\begin{array}{l}\text { - No harmonized } \\
\text { chronologies between } \\
\text { records; } \\
\text { - Peak-warmth centered } \\
\text { map is not representative } \\
\text { of any specific LIG time } \\
\text { interval; } \\
\text { - Limited to marine } \\
\text { records }\end{array}$ \\
\hline 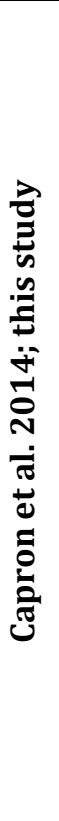 & $\begin{array}{l}\text { - } 42 \text { marine sediment and } 5 \\
\text { ice cores; } \\
\text { - SAT from polar ice cores } \\
\text { based on water stable } \\
\text { is } \phi \text { topes; } \\
\text { - } 42 \text { summer and } 2 \text { annual } \\
\text { SST records based on } \mathrm{U}^{\prime}{ }_{37} \\
\text { planktonic foraminiferal } \\
\mathrm{Mg} / \mathrm{Ca} \text {, macrofossil } \\
\text { assemblage transfer functions } \\
\text { of foraminifera, radiolarian } \\
\text { and diatom assemblages, and } \\
\text { percentage of polar } \\
\text { foraminifera; } \\
\text { - Temporal resolution cut: } \\
<2 \text { ka. }\end{array}$ & $\begin{array}{l}\text { Above } \\
40^{\circ} \mathrm{N} \\
\text { and } \\
40^{\circ} \mathrm{S}\end{array}$ & $\begin{array}{l}\text { - } 115,120,125,127, \\
130 \text { ka time slices; } \\
\text { They are calculated } \\
\text { as the median value } \\
\text { of interpolated } \\
\text { temperature across a } \\
2 \text { ka time window } \\
\text { centered on the } \\
\text { given value. }\end{array}$ & $\begin{array}{l}\text { - Ocean area- } \\
\text { weighted } \\
\text { averages for the } \\
\text { North Atlantic, } \\
\text { Southern Ocean } \\
\text { and Antarctica } \\
\text { (see Table 1); } \\
\text { - } 1870-1899 \\
\text { climatology (this } \\
\text { study); } \\
\text { - WOA } 98 \\
\text { (Capron et al. } \\
\text { 2014). }\end{array}$ & $\begin{array}{l}\text { - Common } \\
\text { temporal } \\
\text { framework build } \\
\text { for marine and } \\
\text { ice records; } \\
\text { - AICC2012 as a } \\
\text { reference age } \\
\text { scale (Bazin et } \\
\text { al. 2012; Veres } \\
\text { et al. 2012); } \\
\text { - Calculation of } \\
\text { surface } \\
\text { temperature on } \\
\text { age scale and } \\
\text { associated } \\
\text { uncertainty } \\
\text { based on linear } \\
\text { interpolation } \\
\text { and Monte Carlo } \\
\text { analysis. }\end{array}$ & $\begin{array}{l}\text { - Harmonized } \\
\text { chronologies; } \\
\text { - Uncertainty estimate } \\
\text { through Monte-Carlo } \\
\text { simulations-; } \\
\text { - Time series between } \\
110 \text { and } 135 \text { ka and } \\
\text { associated with } 2 \sigma \\
\text { uncertainties; } \\
\text { - Ocean area-weighted } \\
\text { regional averages; } \\
\text { - Includes polar ice cores. }\end{array}$ & $\begin{array}{l}\text { - Spatial coverage limited } \\
\text { to high latitude regions; } \\
\text { - Does not include } \\
\text { terrestrial records; } \\
\text { - Relative uncertainty } \\
\text { attached to age markers } \\
\text { estimated visually. }\end{array}$ \\
\hline
\end{tabular}




\begin{tabular}{|c|c|c|c|c|c|c|c|}
\hline 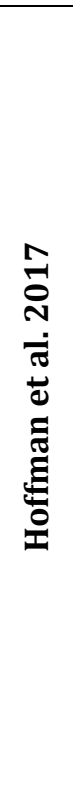 & $\begin{array}{l}\text { - } 83 \text { marine sediment cores } \\
\text { - SST based on } \mathrm{U}^{\mathrm{K}_{37}} \\
\text { planktonic foraminiferal } \\
\mathrm{Mg} / \text { Ca and macrofossil } \\
\text { assemblage transfer function } \\
\text { (foraminifera, radiolarian, } \\
\text { coccoliths, diatoms); } \\
\text { - Temporal resolution cut: } \\
<4 \mathrm{ka}\end{array}$ & $\begin{array}{l}\text { Global } \\
\text { ocean }\end{array}$ & $\begin{array}{l}\text { - } 120,125 \text { and } 129 \\
\text { ka maps; } \\
\text { - Global and regional } \\
\text { temporal stacks } \\
\text { between } 115 \text { and } \\
130 \text { ka; } \\
\text { - Corresponding } \\
\text { surface temperature } \\
\text { taken at the given } \\
\text { value from the } 0.1 \mathrm{ka} \\
\text { interpolated } \\
\text { timeseries. }\end{array}$ & $\begin{array}{l}\text { - 1870-1889 } \\
\text { climatology }\end{array}$ & $\begin{array}{l}\text { - Common } \\
\text { temporal } \\
\text { framework built } \\
\text { for marine } \\
\text { records; } \\
\text { - SpeleoAge as a } \\
\text { reference age } \\
\text { scale (Barker et } \\
\text { al. 2011); } \\
\text { - SST on age } \\
\text { scale and } \\
\text { associated } \\
\text { quantitative } \\
\text { uncertainties } \\
\text { deduced from } \\
\text { Bayesian } \\
\text { statistics and } \\
\text { Monte Carlo } \\
\text { Analysis }\end{array}$ & $\begin{array}{l}\text { - Harmonized } \\
\text { chronologies; } \\
\text { - Uncertainty estimates } \\
\text { through Monte-Carlo } \\
\text { simulations; } \\
\text { - Method to calculated } \\
\text { age models based on } \\
\text { Bayesian statistics; } \\
\text { - Interpolated time series } \\
\text { between } 130 \text { and } 115 \text { ka } \\
\text { and associated } 2 \sigma \\
\text { uncertainties. } \\
\text { - Global and regional } \\
\text { stacks with } 2 \sigma \\
\text { uncertainties; } \\
\text { - Ocean area-weighed } \\
\text { global averages. }\end{array}$ & $\begin{array}{l}\text { - Does not include ice and } \\
\text { terrestrial records; } \\
\text { - Limitations associated } \\
\text { with the use of global } \\
\text { relationships to infer SST } \\
\text { from Mg/Ca from } \\
\text { planktonic foraminifera } \\
\text { and from alkenone ratio. } \\
\text { - Despite a correction } \\
\text { attempt, potential bias } \\
\text { linked to the calculation } \\
\text { of annual SST from the } \\
\text { combination of summer } \\
\text { and winter SST estimates. }\end{array}$ \\
\hline
\end{tabular}

$17 *$ The GRIP ice core is affected by ice mixing near the bedrock preventing a robust dating of the LIG layers and the identification of the LIG maximum

18 warmth (Johnsen et al. 1992). The NorthGRIP ice core unlikely records the LIG maximum warmth as it provides a continuous climatic record extending

19 back to about $123 \mathrm{ka}$ (NorthGRIP project members 2004). 

21 the other syntheses from Turney and Jones (2010), McKay et al. (2011) and Hoffman et al. (2017).

22 At the bottom of the table and for each column, the Root Mean Squared deviation (RMSD) is calculated considering (1) only North Atlantic sites, (2) only

23 Southern Ocean sites and (3) all sites. Sites in italics are sites whose SST records are interpreted as annual signals in the Capron et al. (2014)

24 compilation. 


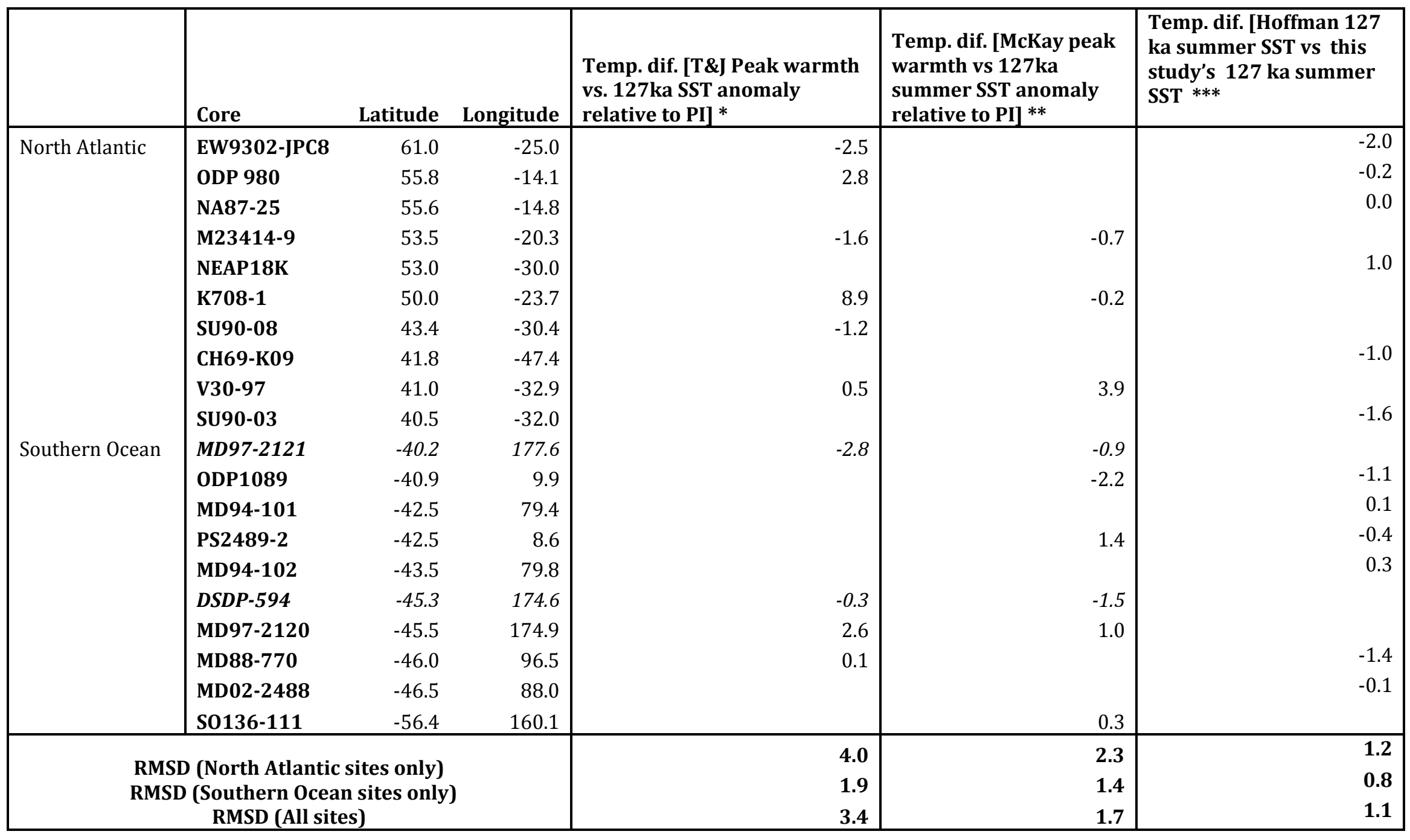

25

* Difference between the LIG peak warmth anomaly relative to the 1961-1990 Mean from Turney and Jones (2010) and the 127 ka surface temperature

27 anomaly relative to the 1870-1899 mean (this study); 

anomaly relative to the 1870-1899 mean (this study);

*** Difference between the 127 ka value from Hoffman et al. (2017) and the 127 ka surface temperature from this study. Note that in this case we only consider sites with identical seasonal interpretation in both the Hoffman et al. (2017) and Capron et al. (2014) syntheses. 
1 Figure 1. Forcing and climatic records across the 110-140 ka time interval. The LIG time interval is indicated by the red vertical dotted lines and

2 horizontal arrow between 129 and 116 ka following the definition based on the eustatic sea level (Masson-Delmotte et al., 2013). Records are displayed 3 in panel( $\mathbf{a}), \mathbf{b}), \mathbf{c}), \mathbf{d})$ and $\mathbf{g}$ ) as anomalies relative to the average value of the last 1000 years. As for the two marine records displayed in $\mathbf{e}$ ) and $\mathbf{f}$ ), the 4 reference summer SST are taken from the World Ocean Atlas 1998 (10m-depth; Capron et al., 2014).

5 a) $21^{\text {st }}$ June across the Northern Hemisphere and $21^{\text {st }}$ December insolation across the Southern Hemisphere respectively;

6 b) Atmospheric $\mathrm{CO}_{2}$ concentration (Lüthi et al., 2008);

7 c) Atmospheric $\mathrm{CH}_{4}$ concentration (Loulergue et al., 2008);

8 d) Greenland NEEM precipitation-weighed temperature reconstruction, (NEEM community members 2012) and associated $2 \sigma$ uncertainty envelope 9 (dotted lines, this study);

10 e) North Atlantic marine core ODP 980 summer SST reconstruction (Oppo et al., 2006) and associated 2 $\sigma$ uncertainty envelope (dotted line; Capron et 11 al. 2014);

12 f) Southern Ocean marine core MD02-2488 SST summer reconstruction (Govin et al., 2012) and associated 2 $\sigma$ uncertainty envelope (dotted lines;

13 Capron et al., 2014);

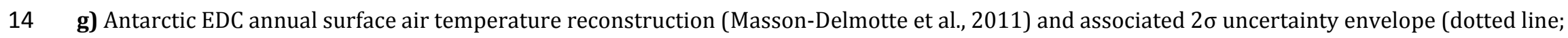
15 this study).

16 h) Maximum global mean sea level (GMSL) relative to present-day, uncertainties remain both in the amplitude (6 to $9 \mathrm{~m}$; indicated by the shading) and 17 in the exact timing of the LIG GMSL peak. However, most studies point toward a late LIG GMSL peak occurring between 119 and 122 ka (see Dutton et 18 al., 2015 for a review).

19 Records on panels $\mathbf{b}$ to $\mathbf{g}$ are displayed on the AICC2012 chronology (Bazin et al., 2012; Veres et al., 2012; Capron et al., 2014). 2 $\sigma$ envelopes associated 20 with surface temperature records on panels $\mathbf{d}$ to $\mathbf{g}$ account both for the relative dating and temperature tracer uncertainties. The vertical yellow line

21 indicates $127 \mathrm{ka}$, the time interval chosen to run the coordinated CMIP6/PMIP4 LIG Tier 1 and Tier 2 simulations. The grey shading indicates the 126-

22128 ka time interval used to build the climate data-based 127 ka time slice. 


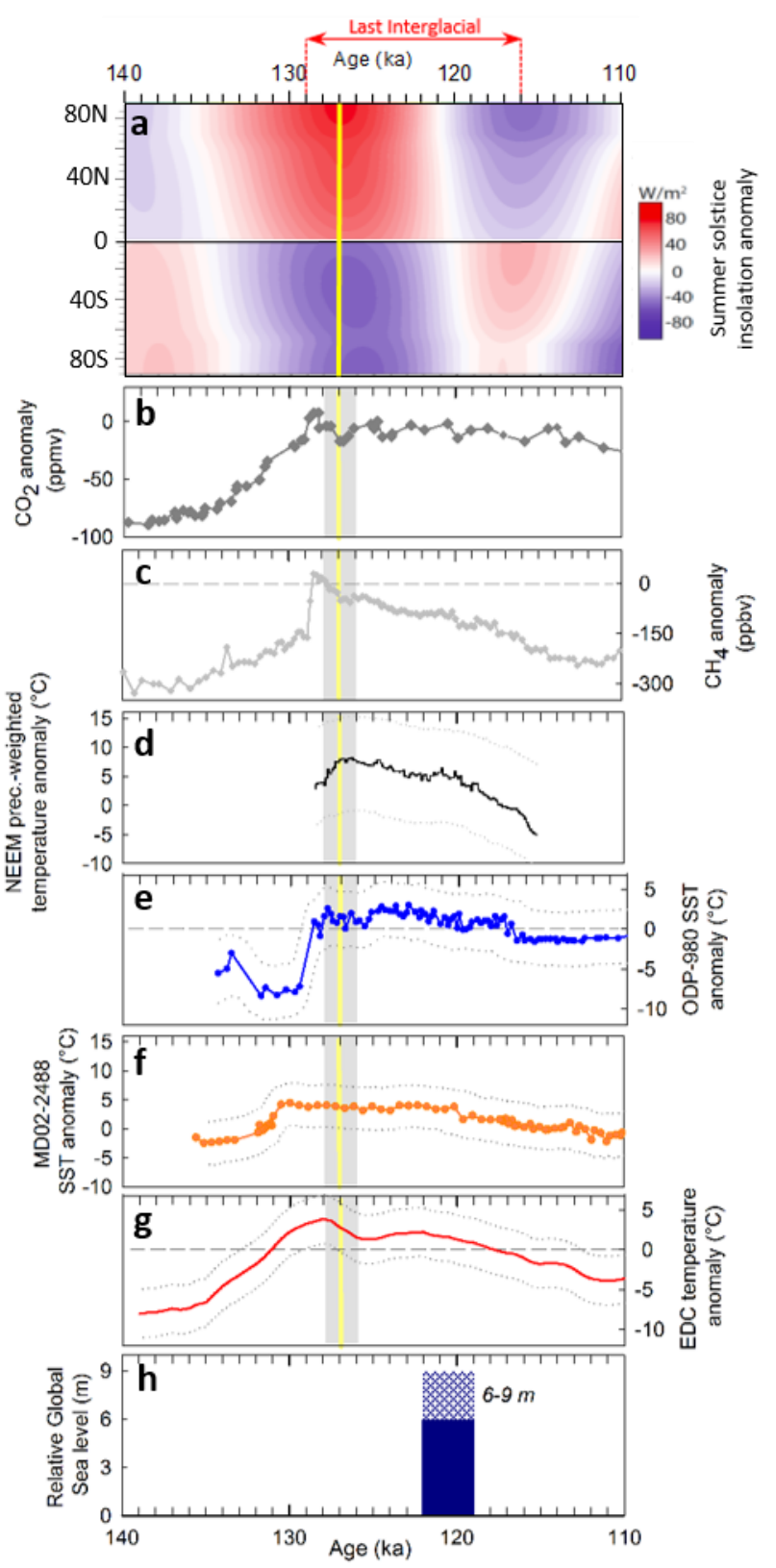


Left panel: Air temperature and SST anomalies (a, c) calculated relative to preindustrial and associated $2 \sigma$ uncertainties of temperature anomalies $(\mathbf{b}$, d) at $130 \mathrm{ka}$ (left), $127 \mathrm{ka}$ (middle) and $125 \mathrm{ka}$ (right) obtained in the Northern Hemisphere (a, b) and the Southern Hemisphere (c, d).

Right panel: Temperature differences $\mathbf{( e , g )}$ and associated $2 \sigma$ uncertainties (f, h) between the 127 and 130 ka time slices (left) and between the 125

28 and 127 ka time slices (right) in the Northern Hemisphere $(\mathbf{e}, \mathbf{f})$ and the Southern Hemisphere $(\mathbf{g}, \mathbf{h})$. The bigger the dot is, the larger the anomaly $(\mathbf{a}, \mathbf{b})$

29 and the uncertainty (c, d) are. Warming (cooling) versus preindustrial temperature is represented in red (blue). Black circles indicate summer signals,

30 white circles indicate annual signals and the star indicates the Greenland site whose temperature record is interpreted as a precipitation-weighted

31 signal (NEEM community members, 2012).

32 Values for the 130 and $125 \mathrm{ka}$ SST anomalies and associated $2 \sigma$ errors are identical to the ones provided by Capron et al. (2014) but some differences

33 exist regarding the 130 and 125 ka surface air temperature estimates and associated uncertainties for reasons described in Section 2. 


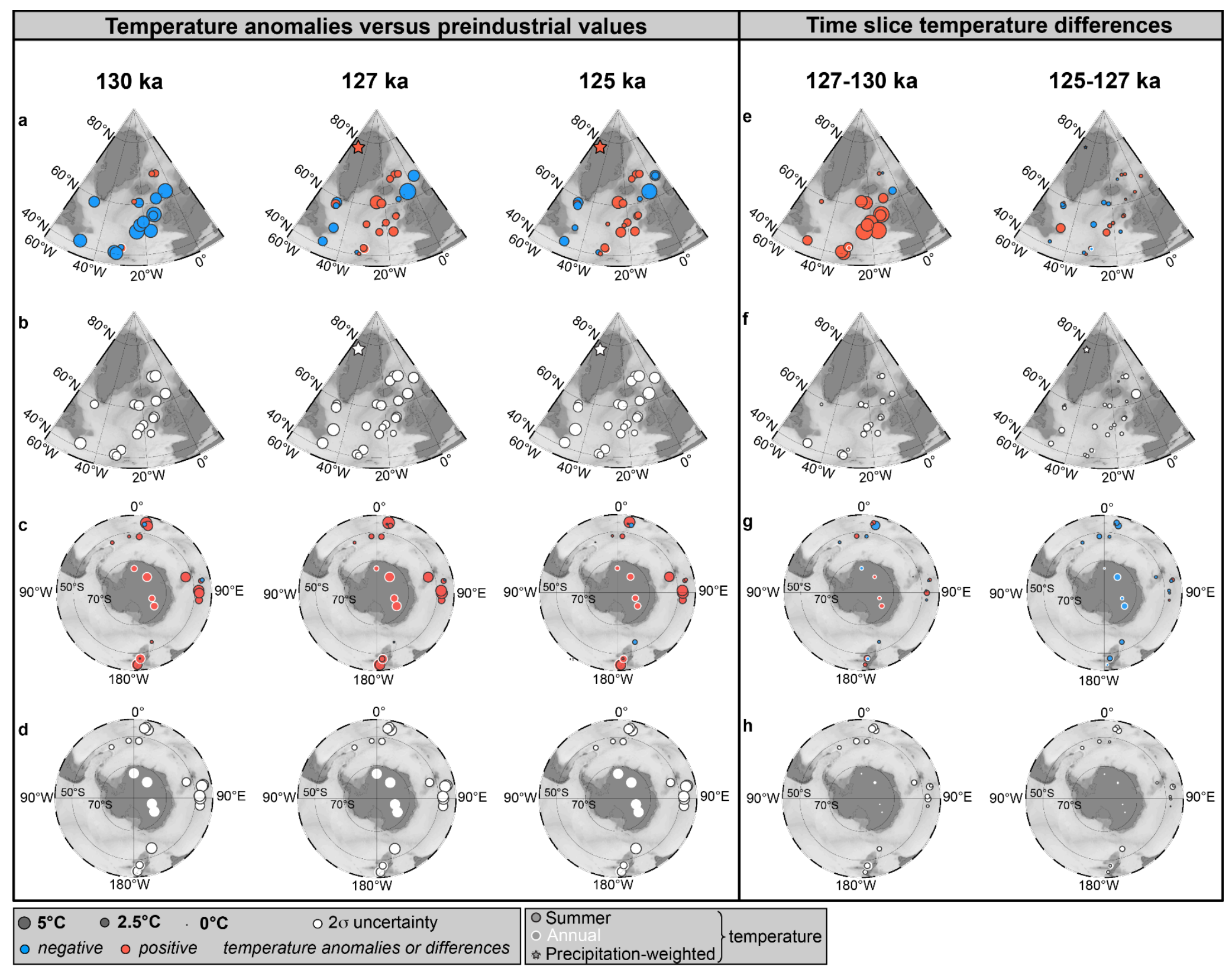


Figure 3. Comparison of four existing LIG surface temperature syntheses in the high latitude regions (poleward of latitude $40^{\circ} \mathrm{N} / \mathrm{S}$ ).

a) The Turney and Jones (2010) synthesis of LIG peak surface warmth relative to the 1961-1990 mean, including reconstructions from terrestrial, marine and ice records and all interpreted as annual signals (white circle);

b) The McKay et al. (2011) synthesis of LIG peak warmth relative to the Late Holocene (last $5 \mathrm{ka}$ ), including marine records interpreted as summer (black circle) or annual signals (white circle), following the information given for each core in the supplementary material of McKay et al., 2011); c) 129, 127 and 125 ka time slices of surface temperature anomaly relative to Preindustrial (1870-1889) including marine records interpreted as summer or annual signals from Hoffman et al. (2017). See Section 4.1 .2 for details on the calculation of the 127 ka based on the Hoffman et al. (2017) synthesis.

d) 130,127 and 125 ka time slices of surface temperature anomaly relative to Preindustrial (1870-1899), including ice and marine records based on the Capron et al. (2014) synthesis. 


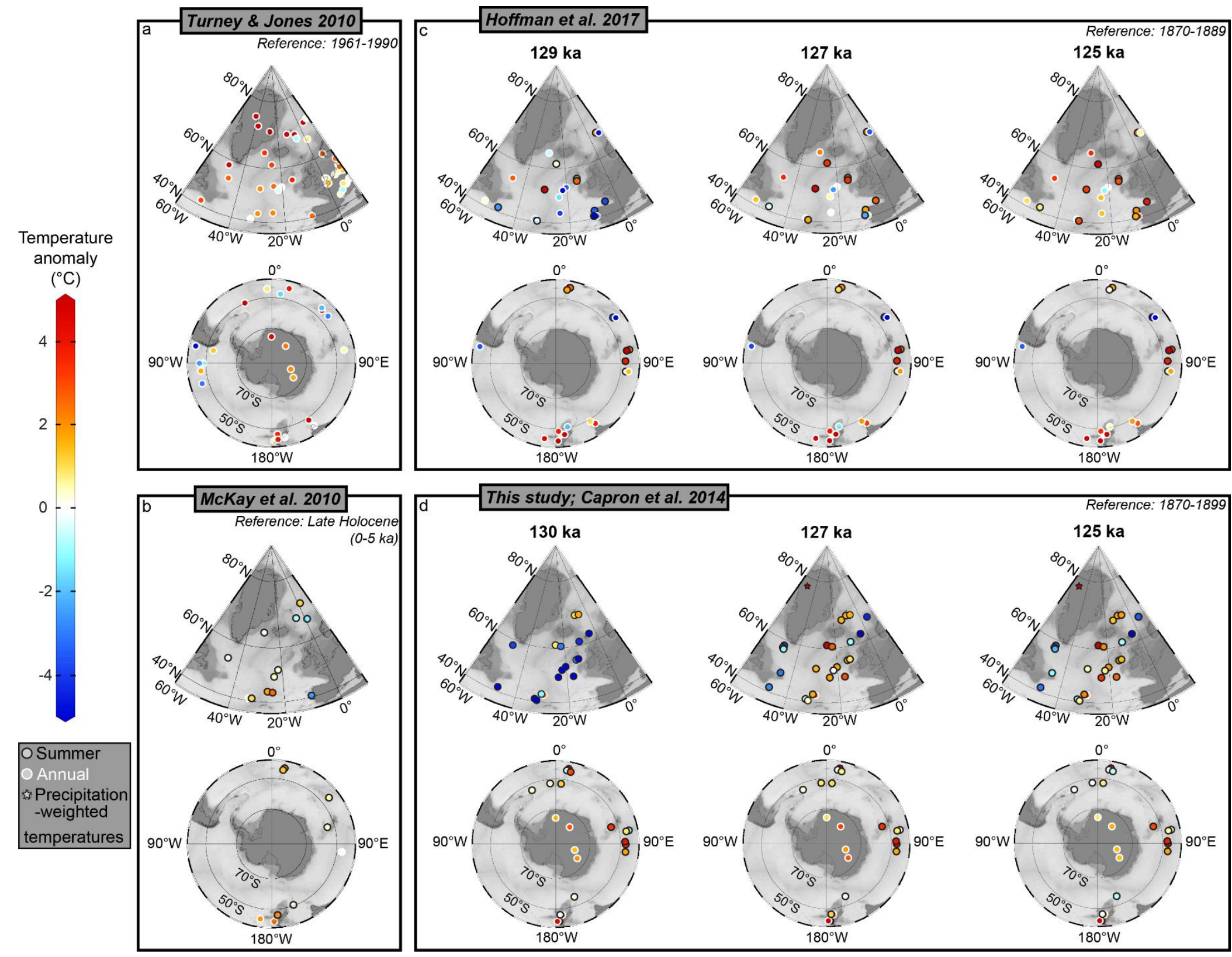


Figure 4. Illustrating the differences resulting from the use of different age methodologies and of different reference time scales as described in Capron et al. (2014) and in Hoffman et al. (2014). The North Atlantic core EW9302-8JPC SST record is used as a case study (Oppo et al., 1997; Oppo et al., 2001). Note that both compilations use the same raw SST dataset on a depth scale.

50 a) The black curve with grey diamonds represents the raw EW9302-8JPC SST data displayed on AICC2012 (Bazin et al., 2012; Veres et al., 2012). The

51 SST data are transferred onto an age scale based on a linear interpolation between the age markers defined by Capron et al. (2014). The thick red line

52 represents the median 100 year-interpolated record and associated non-parametric $2 \sigma\left(2.5^{\text {th }}\right.$ and $97.5^{\text {th }}$ percentiles, dotted red lines $)$ confidence

53 intervals resulting from the 1000 Monte Carlo iterations (methodology described in Section 2 and Capron et al., 2014). The thick blue line represents

54 the mean 100 year-interpolated curve presented on the Asian speleothem-based EDC3 chronology (Barker et al., 2011) as reference age model, and

55 defined using Bchron, a Bayesian age-depth modeling routine (Haslett \& Parnell, 2008) to propagate age and tracer uncertainties. These different

56 methodologies explain the $2^{\circ} \mathrm{C}$ offset obtained at $127 \mathrm{ka}$ (vertical black line) between the red and blue curves.

57 b) EPICA Dome $\mathrm{C}$ water isotopic profile (Jouzel et al., 2007) displayed on the AICC2012 timescale in red and on the SpeleoAge timescale in blue.

58 Horizonal grey arrows indicate the age difference in specific events between the two age scales. An age difference of about 1.4 ka prevails between the

59 two timescales at $127 \mathrm{ka}$. Age differences around 120 and $115 \mathrm{ka}$ illustrate that the choice of a reference timescale becomes increasingly critical at the 60 end of the LIG and over the glacial inception when an offset of more than 3 ka is observed between the two time scales around 115 ka.

61 In both panels, the vertical black line indicates the 127 ka time interval. 


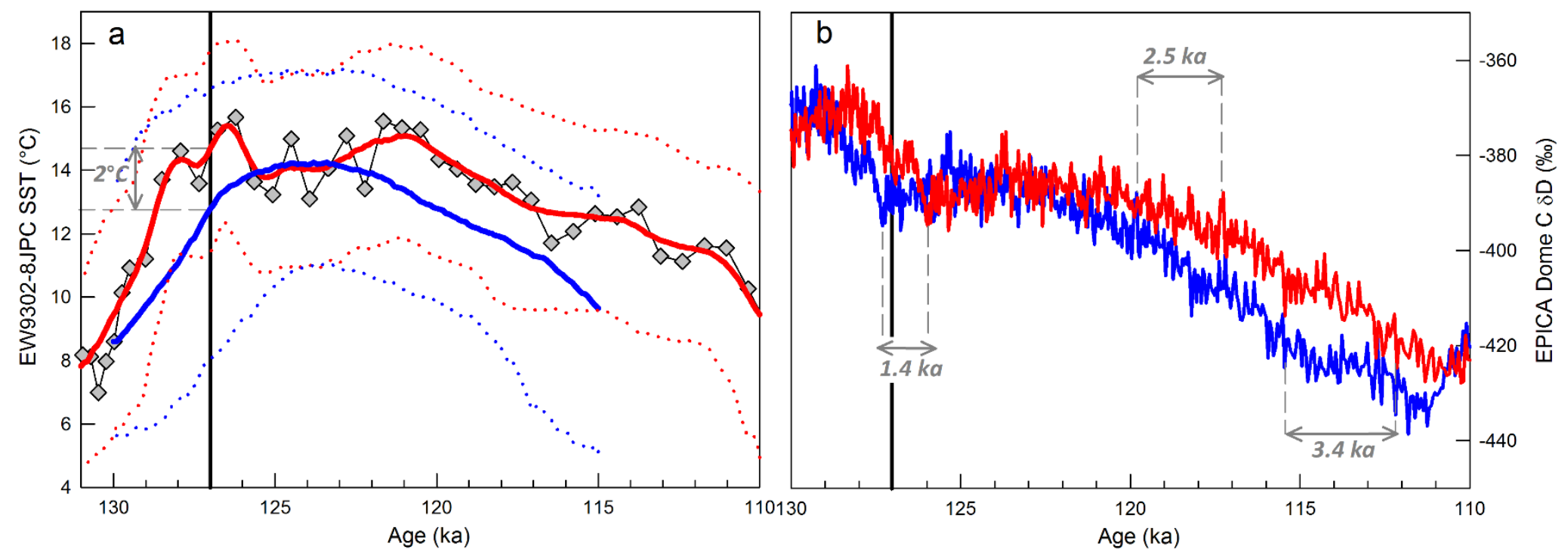

